\title{
Molecular Basis of Aluminium Toxicity in Plants: A Review
}

\author{
Nidhi Gupta', Shailendra Singh Gaurav ${ }^{1}$, Ashwani Kumar ${ }^{2}$ \\ ${ }^{1}$ Department of Biotechnology, Chaudhary Charan Singh University, Meerut, India; ${ }^{2}$ Department of Botany, University of Rajasthan, \\ Jaipur, India. \\ Email: nidhi.05.gupta@gmail.com, Ashwanikumar214@gmail.com
}

Received September $1^{\text {st }}, 2013$; revised October 11 ${ }^{\text {th }}, 2013$; accepted November $15^{\text {th }}, 2013$

Copyright (C) 2013 Nidhi Gupta et al. This is an open access article distributed under the Creative Commons Attribution License, which permits unrestricted use, distribution, and reproduction in any medium, provided the original work is properly cited.

\begin{abstract}
Aluminium toxicity in acid soils having $\mathrm{pH}$ below 5.5, affects the production of staple food crops, vegetables and cash crops worldwide. About $50 \%$ of the world's potentially arable lands are acidic. It is trivalent cationic form i.e. $\mathrm{Al}^{3+}$ that limits the plant's growth. Absorbed Aluminium inhibits root elongation and adversely affects plant growth. Recently researches have been conducted to understand the mechanism of Aluminium toxicity and resistance which is important for stable food production in future. Aluminium resistance depends on the ability of the plant to tolerate Aluminium in symplast or to exclude it to soil. Physiological and molecular basis of Aluminium toxicity and resistance mechanism are important to understand for developing genetically engineered plants for $\mathrm{Al}$ toxicity resistance. This paper provides an overview of the state of art in this field.
\end{abstract}

Keywords: Aluminium Toxicity; Acid Soils; Malate; Citrate; Wheat; Field Crops

\section{Introduction}

It is estimated that around $30 \%$ of the world's total land area consists of acid soils, and about $50 \%$ of the world's arable lands are acidic [1,2]. Moreover, up to $60 \%$ of the acid soils in the world occur in developing countries like in South America, Central Africa and Southeast Asia due to which, food production is critical. Aluminium (Al) is the third most abundant metal found in earth's crust after oxygen and silicon [3]. Al toxicity in acid soils affects the production of staple food crops, particularly grain crops, by decreasing their yield and vigor. Although the poor fertility of acid soils is due to some of the mineral toxicities ( $\mathrm{Al}$ and $\mathrm{Mn}$ ) and deficiencies $(\mathrm{P}, \mathrm{Ca}, \mathrm{Mg}$ and $\mathrm{Mo}), \mathrm{Al}$ toxicity is the most important factor, being a major constraint for crop production on $67 \%$ of the total acid soil area [4].

Acidic soil occurs naturally in tropical and subtropical zones, but in temperate zones, it is the result of acid rain in the industrial regions of the USA, Canada and Europe [5] and this is an increasing problem. Al toxicity is considered as one of the most important limiting factors in agricultural production worldwide [1]. Many of the soils used for agriculture, particularly those in developing countries where forests have been cleared, are considered sufficiently acidic that they restrict the growth of many susceptible plant species. A description of the types of soils that are acid and their distribution is provided by [1].

The naturally occurring forms of $\mathrm{Al}$ are stable and do not interact with the biological processes of living organisms. But, as the soil $\mathrm{pH}$ drops below $5, \mathrm{Al}$ is solubilized into toxic forms like $\left[\mathrm{Al}\left(\mathrm{H}_{2} \mathrm{O}\right)_{6}\right]^{3+}$ which is now presenting in $40 \%$ of the arable lands in the world. Excess $\mathrm{Al}^{3+}$ in soil enters roots [6-8], thus interfering with a wide range of physical and cellular processes, resulting in the inhibition of root growth and function which finally affects other plant parts and related processes and thus reducing crop yields. Not only in plants but, it is also found that it causes problems in humans, also as in nervous system, lungs, and kidney. Even some studies also showed that the people exposed to high levels of aluminum may develop Alzheimer's disease, Parkinson's disease etc.

$\mathrm{Al}$ adversely affects the uptake and transport of essential nutrients, thus affecting the cell division in root tip and lateral roots, increases the rigidity of DNA double helix by reducing DNA replication, cross links pectin, increases cell wall rigidity, reduces root respiration and interferes with enzyme activity related to sugar phos- 
phorylation and the deposition of cell wall polysaccharides. Aluminium toxicity has remained a hot spot in the field of research these days. A number of scientists are highly indulged in studying the physiology, genetics and molecular biology of $\mathrm{Al}$ resistance in crop plants.

Fortuitously, crop plants have evolved resistance mechanisms that enable them to tolerate toxic levels of Aluminium in acid soils [7,9-13]. Resistance to Al can be achieved via exclusion of $\mathrm{Al}$ from the root apex and/or via intracellular tolerance by sequestration of $\mathrm{Al}$ in the plant's symplasm (i.e. "true tolerance"). Although recent evidence for an $\mathrm{Al}$ resistance mechanism involving internal detoxification and sequestration is starting to emerge, the most compelling evidence has focused on a resistance mechanism based on chelation and exclusion of extracellular Al via Al-activated root organic acid release [12,14-16]. An early study in snap bean (Phaseolus vulgaris) [17], followed by a more extensive characterization of the same phenomena in wheat (Triticumaestivum) $[18,19]$, showed that Al-tolerant genotypes exhibit a strong, Al-activated exudation of Al-chelating organic acids (citrate in snap bean and malate in wheat), which is absent or much smaller in the Al-sensitive genotypes.

\section{Aluminium Induced Changes in Physiology and Morphology of Plant}

$\mathrm{Al}$ toxicity is associated with gross changes in root morphology. Briefly, Al toxicity results in inhibited root elongation, which yields swollen root apices and poor or no root-hair development. This extensive root damage results in a reduced and damaged root system which limits water and mineral nutrient uptake $[11,20]$. Long-term exposure to Al results in deficiency of some essential nutrients such as phosphorous, calcium, magnesium, potassium and iron [21] which can be easily detected in plants as deficiency symptoms. The most common responses in shoot and leaves to Al toxicity are curling or rolling of young leaves, small and dark green colouredleaves, reduced stomatal opening, purpling of stems, decreased photosynthetic activity, yellowing and death of leaf tips, chlorosis and foliar necrosis [3]. Interplay of Al to other nutrients like $\mathrm{Ca}$ and $\mathrm{K}$ is reliable indicator of the quality response than the $\mathrm{Al}$ status alone. This all ultimately results in reduced plant biomass [22]. The degree of toxicity reported in the literature varies widely depending on the plant species, growth conditions, Al concentrations, and the duration of the exposure.

\subsection{Effects of Al on Root Cap Function and Root Development}

Aluminium is mainly solubilized in its predominant form i.e. $\mathrm{Al}^{3+}$ form in soil. This is the main toxic form of $\mathrm{Al}$ for crop plants. Aluminium interacts with cell wall, plasma membrane, particularly of the root apex, and rarely with cytoplasm of the plant cell to form Al-complex. Root is the primary site for Al toxicity. In its presence, roots usually become stubby and brittle, root tips and lateral roots become thick and may turn brown which is the visible symptom of $\mathrm{Al}$ toxicity [23]. As the earliest symptoms of toxicity are concerned with roots, thus root growth inhibition can be used as a tool for the measurement of Al toxicity. It was reported that a greater amount of $\mathrm{Al}$ absorbed by plant roots penetrate the boundary between the root apex and root cap and get accumulated in the nuclei and cytoplasm of the cells that are adjacent to this area. While some of the $\mathrm{Al}$ passed through the epidermis cortex, it seems to be that endodermis of the cell prevents $\mathrm{Al}$ from entering into the central cylinder. $\mathrm{He}$ added that some $\mathrm{Al}$ might have by-passed the epidermis by entering the root apex and passing through meristematic cells of the central cylinder. Effects of $\mathrm{Al}$ on plant root can be examined by observing the different segments of the root cell.

\subsection{Al Toxicity at Cellular Level}

The complexity of the many cellular processes involved in root growth inhibition, the precise Al toxicity targets in this complex chain of events remain elusive. Al binding to plasma membrane phospholipids surrounding trans-membrane transporters may induce local charge disturbances and alter local ion concentrations, thus effects ion movement to binding sites in membrane transport proteins. One of the most noticeable consequences of root $\mathrm{Al}$ exposure is an almost instantaneous depolarization of the plasma membrane $[24,25]$. This change in the trans-plasma membrane electrochemical potential may be due to both direct and indirect interactions of $\mathrm{Al}$ with a number of different ion transport pathways [26].

\subsubsection{Cell Wall}

Al primarily and predominantly gets accumulated in the root apoplast which covers $30 \%-90 \%$ of the total absorbed Al of peripheral cells in plant $[27,28]$ which is then slowly translocated to other central tissues $[29,30]$. The primary binding of $\mathrm{Al}^{3+}$ in the apoplast is probably the pectin matrix, with its negatively charged carboxylic groups [30,31]. Al absorption in the plant cell wall reduces the movement of water and solutes through the apoplasm which finally and directly decreases nutrient acquisition by the root [32]. Consequently, the strong and rapid binding of $\mathrm{Al}$ can alter cell-wall structural and mechanical properties, making it more rigid, leading to a reduction in the mechanical extensibility of the cell wall required for normal cell expansion in the root elongating zone [13].

$\mathrm{X}$-ray microanalysis and secondary ion mass spectro-analysis techniques are used to determine the amount 
of Al which is associated with apoplastic binding sites. The net negative charge on the cell wall determines its Cation Exchange Capacity (CEC) and consequently the degree to which $\mathrm{Al}$ interacts with the cell wall. Aluminium crosses links with pectin and increases cell wall rigidity thus leading to decrease in the mechanical stability and ultimately decrease in cell growth. Cell wall cations are strongly replaced by $\mathrm{Al}$, finally resulting in drastic change in cell wall structural and mechanical properties [30,33-35].

\subsubsection{Apoplast}

Isotopic tracer studies using $\mathrm{Mg}^{2+}$ demonstrated the existence of the apoplasmic pathway for $\mathrm{Mg}^{2+}$ ions in the cortex of mycorrhizal roots of Norway spruce [36]. Further, entry of $\mathrm{Mg}^{2+}$ into the endodermis was faster through the apoplasmic than the symplasmic pathway [36]. Given this importance of the apoplasmic pathway for $\mathrm{Mg}$ uptake and transport, it should be borne in mind that in $\mathrm{Al}^{3+}$ toxicity large amounts of $\mathrm{Al}(85 \%-99.9 \%$ of total cellular Al) accumulate in the cell walls and intercellular root spaces $[14,37,38]$. More specifically, binding of Al to the negative charges on the pectin substances in the cell wall was observed [32]. Such binding of Al on the cell wall and precipitation of $\mathrm{Al}$ in the apoplast may decrease loading of $\mathrm{Mg}^{2+}$ ions into the apoplast and movement via the apoplasmic pathway.

\subsubsection{Plasma Membrane}

Plasma membrane is a dynamic quasi fluid structure which forms the external boundary of the cells. Membranes viewed as quasi-fluid structures are those in which proteins are inserted into the lipid bilayers. Al can interact strongly with the negatively charged plasma membrane. Depending on $\mathrm{pH}$ and other factors, Al can bind either to proteins or to the lipids. It can displace other cations like $\mathrm{Ca}$ that may form bridges between the phospholipid head groups of the membrane bilayer [39]. As aluminum has greater affinity for the choline head of phosphotidyl choline, a lipid constituent of the plasma membrane, it displaces other cations that are present on negatively charged plasma membrane and then binds itself. Depolarization of the plasma membrane is one of the consequences of the Al toxicity [25]. Al interaction with plasma membrane could lead to depolarization of the trans-membrane potential [40] and/or reduction of $\mathrm{H}^{+}$-ATPase [41] which, in turn, can alter the activities of ions near the plasma membrane surface and impede the formation and maintenance of the trans-membrane $\mathrm{H}^{+}$ gradient [13]. Moreover, Al changes in plasma membrane can modify the uptake of several cations (e.g., Ca, $\mathrm{NH}^{4+}$ ) [42-44]. These changes are related to direct $\mathrm{Al}^{3+}$ interactions with plasma membrane ion channels [43] and changes in membrane potential. This may cause nu- tritional imbalances induced by $\mathrm{Al}$ exposure.

Displacement of cations by $\mathrm{Al}$ results in the excessive synthesis of callose $(\beta-1,3$-glucane $)$ on the plasma membrane by $\beta$-1, 3-glucanesynthetase. Accumulation of callose may lead to the further cellular damage by inhibiting intercellular transport through plasmodesmatal connections [45]. Thus the callose formation can be taken as a parameter of $\mathrm{Al}$ sensitivity and is positively correlated with pectin content [30]. Increase in the pectin content results in higher $\mathrm{Al}$ content of the cell, clearly indicating that pectin plays a major role in the binding of $\mathrm{Al}$. Therefore, Al-sensitivity is found in cells having high pectin content while the cells with less pectin content seems to be Al-resistant. Accumulation of Al depends on the degree of dissociation of carboxylic and hydroxylic groups of the pectin [46]. Aluminium directly or indirectly interacts with a number of different ion transport pathways resulting in change in the transplasma membrane electrochemical potential [26].

It has been well established that $\mathrm{Al}$ can enter the symplasm of root cells quite rapidly $[47,48]$ and can be sequestrated in the vacuole after $30 \mathrm{~min}$ [38]. Indeed, putative plasma membrane-localized Al transporter, Nrat1 (Nrampaluminium transporter 1), has been identified recently in rice [49], but it remains unclear whether it is specific for $\mathrm{Al}^{3+}$ or can transport other cations also. The Al entry into the cytoplasm affects the homeostasis of various ions, such as $\mathrm{H}^{+}[50], \mathrm{Ca}^{2+}[51,52]$, and $\mathrm{K}^{+}$[53].

\subsubsection{Plasma Membrane $\mathrm{H}^{+}$-ATPase}

Activity of the plasma membrane $\mathrm{H}^{+}$-ATPase is inhibited by the presence of Al which ultimately affects the formation of trans-membrane $\mathrm{H}^{+}$gradient $[54,55]$. For secondary ion transport processes trans-membrane $\mathrm{H}^{+}$gradient plays a major role. Therefore disruption of $\mathrm{H}^{+}$gradient could indirectly alter the ionic status and ion homeostasis of root cells.

\subsubsection{Cytoskeleton}

The orientation of cytoskeleton provides a template both for cell division and cell wall biosynthesis [56]. It is believed that because of the central importance of cytoskeletal components (microtubules and microfilaments) in cell division, it is a main target for Al toxicity [57-66]. Cytoskeletal dynamics can be disrupted either by directinteraction with cytoskeletal elements (i.e., microtubules and actin filaments) or indirectly by altering cytosolic $\mathrm{Ca}^{2+}$ levels that are involved in cytoskeletal stabilization. $\mathrm{Al}$ exposure can disrupt both the organization of microtubules and microfilaments in root cells [59-64]. For example, exposure to $\mathrm{Al}$ results in the disruption and reorganization of cortical microtubules. Likewise, Al induced a significant increase in the tension of the actin filaments of soybean (Glycine max) cells [67]. 


\subsubsection{Mitochondria}

A recent study demonstrated that Rhodotorulaglutinis has 2.5 to 3 folds more mitochondria in Al-resistant yeast strain than the wild-type strain [68]. The $\mathrm{Mg}^{2+}$ ions are essential for normal functioning of mitochondria as their deficiency often results in mitochondrial disintegration [69], reactive oxygen species (ROS) production, and photo-oxidative damage in many plant species [70]. Plant cells also have numerous mitochondria; however, no direct correlation has yet been established between abundance of mitochondria and $\mathrm{Al}$ resistance. $\mathrm{Mg}$ ion might be an important component of characterizing the physiology of $\mathrm{Al}$ resistance. $\mathrm{Al}^{3+}$ toxicity may also provoke similar mitochondrial dysfunction [71] and ROS production in many plant species [72-76] presumably by causing $\mathrm{Mg}$ deficiency inside the mitochondria or by substituting $\mathrm{Mg}$ for $\mathrm{Al}^{3+}$ in $\mathrm{Mg}^{2+}$-dependent enzymes $[77,78]$. Thus, mitochondrial $\mathrm{Mg}$ porters could be the target site for $\mathrm{Al}^{3+}$ toxicity.

\subsubsection{DNA/Nuclear Damage}

After interaction with cell wall and cell membrane, Al interacts with the structures within the nucleus detrimentally affecting DNA composition, chromatin structure and template activity. Al reduces DNA replication by increasing the rigidity of the double helix. [79,80] reported that the application of $\mathrm{Al}(0.2-1.0 \mathrm{mM})$ inhibits cell division and cell viability.

\section{Effect of Aluminium on Shoot}

Ten barley cultivars were tested and screened out for Al tolerance by growing them for 25 days in the greenhouse in pots containing acid soil and Al toxic Tatum subsoil [81]. It was reported that relative shoot dry weight averaged $28.6 \%$ for tolerant and $14.1 \%$ for sensitive cultivar groups. In shoots of sensitive cultivar, Al concentration at $\mathrm{pH} 4.4$ was found to be three times higher than in those of the tolerant group. 15 Durum wheat (Triticum durum Desf.) cultivars were also tested for Al tolerance at $\mathrm{pH} 5.7$ [81]. Concentrations of $\mathrm{Al}$ and phosphorous were significantly higher in shoots of sensitive lines as compared to the tolerant one, grown in acid soils. For the first time, they demonstrated that Al tolerant group of wheat was able to increase $\mathrm{pH}$ in nutrient solutions comparatively to Al sensitive cultivars, when both are tested with or without Al. [82] tested two cultivars of Coleus blumei in nutrient solution containing $0-24 \mathrm{mg} / \mathrm{L} \mathrm{Al}$ and in Al-toxic tatum subsoil under greenhouse conditions. Inhibitory effects of Al-toxicity were observed on shoot growth, that were cultured in nutrient solution having $\mathrm{Al}$ concentration $8 \mathrm{mg}$ or above, while inhibition of root growth was observed in solution having $\mathrm{Al}$ concentration $16 \mathrm{mg} / \mathrm{L}$ or above.

\section{Nutritional Imbalance}

Nutritional imbalances induced by Al exposure were reported in several plant species by many researchers. Al interferes with the uptake, transport and utilization of most of the mineral elements. Under $\mathrm{Al}$ stress, the uptake of many cations including $\mathrm{Ca}^{2+}(69 \%), \mathrm{Mg}^{2+}, \mathrm{K}^{+}(13 \%)$ and $\mathrm{NH}^{4+}(40 \%)$ is inhibited while the influx of the anions of nitrate $(44 \%)$ and phosphate $(17 \%)$ get enhanced. Mineral nutrition was most often accompanied by increased $\mathrm{H}^{+}$release in Sorghum [83], Maize [84], Wheat and Soybean. [85] reported that $\mathrm{Mg}^{2+}$ was more effective than $\mathrm{Ca}^{2+}$ in alleviating $\mathrm{Al}$ stress in monocotyledons whereas vice-versa for the dicotyledons. Al-sensitive cultivars were characterized by chlorosisin $\mathrm{Al}$ stress in nutrient solution, decreased $\mathrm{Fe}$ concentrations in tops, decreased $\mathrm{Ca}$ and $\mathrm{Mg}$ in shoots and roots both, a tendency towards accumulation of $\mathrm{Al}, \mathrm{P}$ and Fe in roots, and reduced $\mathrm{Mn}$ in tops. Eleven families of pteridophytes presented different nutritional imbalances, mostly in $\mathrm{Ca}$, $\mathrm{Mg}, \mathrm{P}, \mathrm{K}$ depending on $\mathrm{Al}$ accumulation [86]. In maize, Al resulted in negative effects on the uptake of micro ( $\mathrm{Mn}$ and $\mathrm{Zn}$ ) and macronutrients ( $\mathrm{Ca}$ and $\mathrm{Mg}$ ) [87] and $\mathrm{K}$ [88] than the Al-sensitive genotypes. Both sensitive and tolerant genotypes of wheat had presented a decrease in $\mathrm{K}$ and $\mathrm{Mg}$ contents in roots, whereas $\mathrm{Ca}, \mathrm{Al}, \mathrm{Si}$ contents increased [89]. It was reported that $\mathrm{NO}^{3-}$ uptake by soybean was decreased when $\mathrm{Al}$ concentration in solution increased from 10 to $50 \mu \mathrm{M}$ [90] whereas, $\mathrm{Al}$ reduced $\mathrm{Cl}^{-}$and $\mathrm{NO}^{3-}$ uptake in maize [91].

It is also observed that Al toxicity is closely related to nitrogen metabolism [92]. It was noted that nitrate reductase activity was higher in Al tolerant cultivars, when grown in Al treated nutrient solution [93]. Al interfered with the binding of the cations in the cell wall by the same order of magnitude as their respective influxes whereas phosphate binding was strongly enhanced [94]. Some suggested that $\mathrm{Ca}^{2+}$ that plays an important role in mechanism of resistance against $\mathrm{Al}$ toxicity is particularly inhibited by $\mathrm{Al}^{3+}$ [95]. Due to the deficiency or reduction of $\mathrm{Ca}^{2+}$ ion transport and disruption of cellular $\mathrm{Ca}^{2+}$ homeostasis, root growth of a plant is inhibited. $\mathrm{Al}$ toxicity appears as an induced Ca deficiency or reduced $\mathrm{Ca}$ transport problem. Excess $\mathrm{Al}$ even induces iron $(\mathrm{Fe})$ deficiency symptoms in rice (Oryza sativa L.), sorghum and wheat $[92,96,97]$.

\section{Deficiency of Phosphorous}

Phosphorous is the main component of several biological compounds such as nucleic acids, phospholipids and ATP. It also acts as a metabolite involved in energy transfer, the activation of proteins and the regulation of metabolic processes $[98,99]$. Inorganic phosphate is the primary source of phosphorous for plants. It enters into 
the equilibrium reactions defined by $\mathrm{P}$-sorption isotherm [100]. Even in the most fertile soils, $P_{i}$ concentration in soil solutions rarely exceeds $8 \mu \mathrm{M}$ [101]. For the increment in the $\mathrm{P}_{\mathrm{i}}$ concentration, plants have adapted a number of morphological and biochemical strategies. Highly branched root systems with more root apices are highly capable of acquiring phosphorous. Therefore, the surface area of roots in contact with the soil, increased in some species by an increase in diameter of roots when the plants are P-stressed [15] and both the density and length of root hairs may increase [102-104]. As Al-toxicity highly affects root development, as a result phosphate deficiency occurs in plant whose adverse effect can be seen in plants growth. Deficiency of phosphorous in plant that grows on acid soils or in nutrient solution is caused because of $\mathrm{Al}$ interference with phosphorous.

\section{ROS (Reactive Oxygen Species)}

Aerobic processes such as respiration and photosynthesis led to the formation of ROS in mitochondria, chloroplasts, and peroxisomes [12]. Different types of ROS are found in plant cell but the common property among them is that they all have the capacity to cause oxidative damage to proteins, DNA and lipids and ultimately results in the death of a cell. ROS are mainly synthesized as signaling molecules in plants and are involved in regulating development and pathogen defense responses. But their production in higher amounts can affect the cell metabolism. The imposition of biotic and abiotic stresses can give rise to further increases in ROS levels. Metals, including $\mathrm{Al}$, are known to act as catalysts in ROS production and to induce oxidative damage in plants. Large number of swollen mitochondria with many vacuoles, structural disturbances of the plasma membrane, and preapoptotic nuclear structures were some of the characteristic features of $\mathrm{Al}$ treated tobacco cells, confirming that Al signaling follows the mitochondrial pathway of cell death. Plant cells are well equipped with complex non enzymatic antioxidants such as ascorbate, glutathione, tocopherol and carotenoid, and with enzymatic antioxidants such as catalase, ascorbate peroxidase, guaiacol peroxidase, superoxide dismutase (SOD), mono dehydroascorbatereductase, dehydroascorbatereductase, glutathione-S-transferase (GST) and glutathione reductase, which help to detoxify the ROS.

Different types of anti-oxidative defense components are present in cellular compartment that cause scavenging of ROS. But the equilibrium between production and scavenging of ROS may be perturbed by a number of adverse environmental factors: Al-toxicity is one of them. Al exposure leads to oxidative stress [74,105-107]. Under environmental stress, for example, Al-stress plant cells generate ROS by activating various oxidases and peroxidases. Because $\mathrm{Al}$ ions form electrostatic bonds preferentially with oxygen donor ligands (e.g., phosphate groups or carboxylate), cell wall pectin and the outer surface of the plasma membrane seem to be major targets of $\mathrm{Al}$ [108].

"Oxidative burst" is the condition when there is a rapid increase in ROS concentration. Toxicity of ROS has often been monitored by measuring lipid peroxidation. Polyunsaturated fatty acids within the lipids are preferred target of ROS attack. Enhancement in lipid peroxidation occurs under prolonged $\mathrm{Al}$-stress and results in formation of highly toxic oxygen free radicals [105].

\section{Anti-Oxidant Enzymes}

Antioxidant enzymes that act as scavengers of ROS are activated during Al-stress [109]. Enzymatic ROS scavenging mechanism that acts as the first line of defense system in plants, include-superoxide dismutase (SOD), ascorbate peroxidase (APX), glutathione peroxidase (GPX), and CAT. SODs act as the first line of defense against ROS, dissimulating superoxide to $\mathrm{H}_{2} \mathrm{O}_{2}$. APX, CAT and GPX subsequently detoxify $\mathrm{H}_{2} \mathrm{O}_{2}$ [110].

\section{Mechanism of Aluminium Tolerance in Plants}

Al toxicity and tolerance mechanisms differ in plants according to its chemical form, and the study of $\mathrm{Al}$ related processes are complicated by the complex chemistry of Al. There are several recent reviews/researches that discuss mechanisms of Al tolerance and toxicity in plants by $[7,9,15,16,111-115]$. Al toxicity affects a number of cellular components such as composition, physical properties and structure of the plasma membrane [116,117], cell nuclei, mitosis and cell division [Silva, et al., 2000], uptake of $\mathrm{Ca}^{2+}$ and other ions [118] and cytoskeletal dynamics [56] and many more. Primary target of Al toxicity is the disturbance of cytoplasmic $\mathrm{Ca}^{2+}$-homeostasis [52] and may be involved in the inhibition of the cell division. In wheat root apices, it was found that $\mathrm{Al}$ inhibits $\mathrm{Ca}^{2+}$-dependent phospholipase $\mathrm{C}$, which acts on the lipid substrate phosphatidylinositol-4, 5-biphosphate. It was hypothesized that phosphoinositide signaling pathway might be the initial target of $\mathrm{Al}$ [119].

\section{Cultural Practices}

\subsection{Altering Soil pH}

Liming has been attempted for checking soil acidity and provides resistance against Al toxicity. However, use of lime as a main application for managing acid soils is either too costly or takes many years to be effective particularly where the acidity occurs at depth. 


\subsection{Crop Rotation}

On acid soils, Al sensitive species can be replaced by Al tolerant species to maintain crop production. For example, replacement in pastures alfalfa from $\mathrm{Al}$ sensitive to more Al-tolerant pasture species but the drawback with this approach is that the nutritional quality of the alternative pastures might not match that of alfalfa.

\subsection{Breeding for Resistance}

Breeders can use even little variation within a species to enhance the $\mathrm{Al}$ tolerance of elite genotypes. For example, a small number of major dominant genes control Al tolerance in wheat (Triticum aestivum) and breeders exploit this property in breeding programs to enhance $\mathrm{Al}$ tolerant cultivars [120-122]. Root growth inhibition is the first symptom of $\mathrm{Al}$ toxicity and the use of defined concentrations of $\mathrm{Al}$ in hydroponic culture has proven to be a reliable measure of $\mathrm{Al}$ tolerance for a number of species. The hematoxylin stain is also one of the useful parameter in determining the $\mathrm{Al}$ tolerance of plants [123].

\section{The Complex Role of Organic Acids in Detoxifying $\mathrm{Al}^{3+}$}

It is estimated that over a dozen of Al-tolerant plant species secrete organic acids from their roots in response to $\mathrm{Al}$-stress. Al resistance is correlated with the Al-induced secretion of organic acids like citrate, oxalate or malate [124-127]. Some of the organic acid that are secreted by plants such as citrate, oxalate, malate etc., which are anionic in nature, form complexes with $\mathrm{Al}^{3+}$ in order to protect plant roots [15]. Al-resistant cultivars of snapbean (Phaseolus vulgaris) excreted eight folds more citrate from the roots than did an Al-sensitive genotype, is the first evidence in the field of Al-resistance mechanism $[12,17]$. Malate is released from the roots of Al-tolerant cultivars of wheat (Triticum aestivum), citrate from Altolerant cultivars of snapbean (Phaseolus vulgaris), maize (Zea mays), Cassia tora and soyabean (Glycine max) and oxalate from buckwheat (Fagopyrum esculentum) and taro (Colocasia esculenta). Some plant species such as Al-tolerant triticale, rapeseed (Brassica napus), oats (Avenasativa), radish (Raphanus sativus) and rye (Secale cereal) release both malate and citrate $[15,17$, 128-135].

It was found that $\mathrm{Mn}, \mathrm{La}, \mathrm{Cd}$, or $\mathrm{Pb}$ treatment did not induce the secretion of organic acids. Even P deficiency during $\mathrm{Al}$ treatment was also not responsible for Al-induced secretion of organic acids. Constitutive phosphate secretion might operate in conjunction with the Al-induced secretion of organic acids to confer $\mathrm{Al}$ resistance in certain wheat genotypes [136]. In Cassia toraor buckwheat, neither $\mathrm{P}$ deficiency nor application of $\mathrm{La}$ or $\mathrm{Yb}$ induced secretion of organic acid $[126,127,132]$. It was reported that La failed to induce secretion of malate in Al-resistant cultivars of wheat [137]. Aluminum resistance in the arabidopsis mutant alr-104 is caused by an Al-induced increase in rhizosphere $\mathrm{pH}$ [138]. Thus, it was observed that the secretion of organic acid from roots was a specific response to Al stress $[129,139,140]$. In these examples, it was observed that the efflux of organic acids occurs primarily from the root apices and this proves somewhere that the plant root system is most susceptible to Al toxicity. Moreover, the finding that Altolerant genotypes exude more organic acid than the Al-sensitive genotypes supports the hypothesis that the organic acid efflux is an $\mathrm{Al}$ tolerance mechanism.
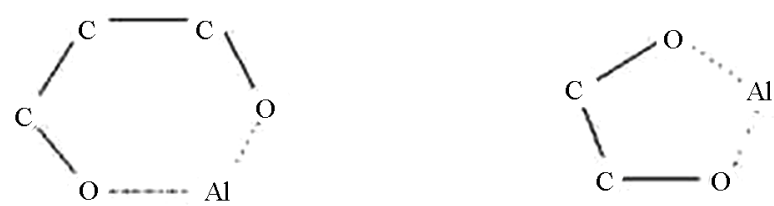

5- or 6-membered ring structures of organic acid with $\mathrm{Al}^{3+}$ to protect the plants from Al toxicity.

Thus, there are now a number of evidences which proves that organic acids play an important role in the $\mathrm{Al}$ tolerance mechanisms in different plant species. Some organic acids are able to form non-toxic complex with $\mathrm{Al}^{3+}$. It was observed a range of different organic acids that chelate the $\mathrm{Al}$ and therefore protect the roots from $\mathrm{Al}$ toxicity in hydroponic culture [141]. They found that an organic acid with hydroxyl and carboxyl groups shows greatest protection from $\mathrm{Al}$ toxicity. Al tolerance mechanisms suggested that organic acids can be divided into external and internal detoxification and some plant species are using both types of mechanisms.

Two patterns of organic acid secretion have been observed. In first pattern, no discernible delay was observed between the addition of $\mathrm{Al}$ and the onset of organic acid release. For example, in beet and buckwheat, the secretion of malate and oxalate respectively was detectable within 15 - 30 min after exposure to $\mathrm{Al}[15,128,132]$. In second pattern, delayed secretion of organic acids, for several hours after exposure to $\mathrm{Al}^{3+}$, was observed. For example, after 4 hours exposure to $\mathrm{Al}$, maximal efflux of citrate occurs in C. tora [130] and in rye, malate and citrate efflux increases steadily during 10 hour period [134]. It is believed that in first pattern, transporter on the plasma membrane might be activated by $\mathrm{Al}$ to initiate anion efflux and there is no need of novel proteins. Some authors suggested that in Pattern I, Al activates a preexisting transport mechanism for malate and a role for anion-channels in the transport of the organic acid. While little information is available about the mechanism of Pattern II as it is estimated that in second pattern, protein induction is required. These proteins could be in- 
volved in transporting organic acids out of the root cells and/or in the synthesis of organic acids.

Some of the major aspects of this resistance mechanism include [12]:

1) Al forms complexes with carboxylate that are not further transported into roots or across the membranes $[142,143]$.

2) Exogenous $\mathrm{Al}^{3+}$ induces secretion of carboxylate [124].

3) Over expression of genes encoding enzymes involved in organic acid synthesis such as citrate synthase and malate dehydrogenase results in enhanced Al-resistance in some plant species [144-146].

4) Al-resistance co-segregates with Al-induced malate release in wheat and Arabidopsis [18,19,147].

5) An Al gated anion channel in maize (Zea mays) and wheat root tip protoplasts has been identified via electrophysiological experiments, and exhibits the properties necessary for it to be the transporter mediating Al-activated carboxylate release [43,148-150].

It is also observed that the amount of organic acid released from root apices need not to detoxify all $\mathrm{Al}$ in the soil surrounding the root system. Detoxification of Al that immediately surrounds the root apices is quite sufficient. However, it is also required to replace organic acids that are broken down by microorganisms as well as to replace organic acids that diffuse away from the root apex. It is suggested that when organic acid moves through an acid soil, it acts as a protective sheath around the root apex.

\section{Anion Channels and the Efflux of Organic Anions}

At $\mathrm{pH} 7$ of the cytoplasm, organic acids are dissociated in their anionic forms from their protons. Both the concentration gradient for the organic anions and the electrochemical gradient across the plasma membrane helps in the efflux of organic anions out of the cells. As organic anions are the charged molecules, they move through the hydrophobic lipid bilayer of the plasma membrane. Organic anions might be released in two conditions, 1) if the plasma membrane gets damaged, because of any natural phenomenon which results in cell leakage and finally cell death, 2) efflux of organic acids due to Al toxicity. However, second one is a controlled process and can be stopped or reduced when $\mathrm{Al}$ is removed from the medium. Thus, rupture of the plasma membrane is not actually responsible for the efflux because, only one or two organic anions are exuded from roots, in response to Al. Furthermore, it is also observed that $\mathrm{Al}$ tolerant genotypes efflux more organic ions than the sensitive genotypes, where Al toxicity results in damage to the plasma membrane (Figure 1).

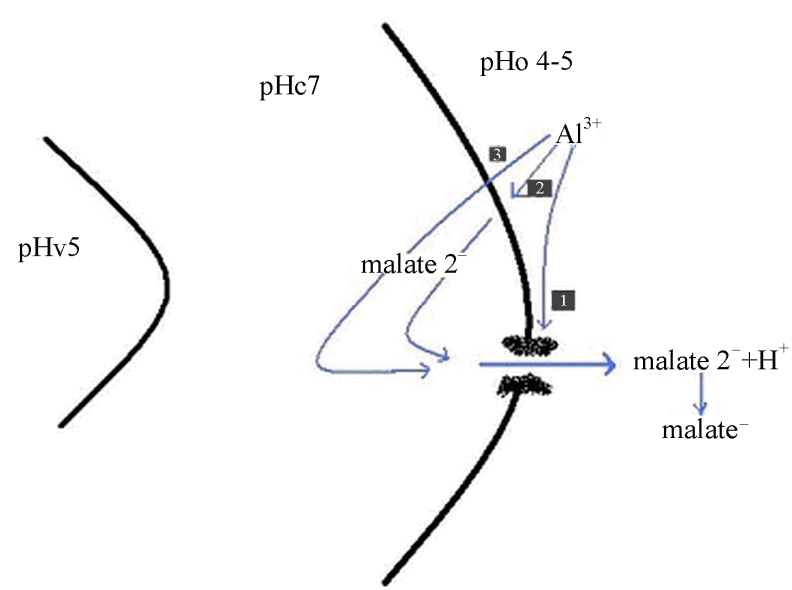

Figure 1. Mechanism of Al activated efflux in the plant root tip cells. Three possibilities are shown where Al interacts (1) with the channel protein directly or (2) with any component of the plasma membrane or (3) it enter the cell to trigger the opening of the channel for malate efflux. The malate has the capacity to chelates $\mathrm{Al}^{3+}$ thus makes it nontoxic.

\section{Carboxylate Transporter}

For translocation of organic anions across the plasma membrane, difference in $\mathrm{pH}$ or $\mathrm{H}^{+}$activity between the cytoplasm and the apoplasm plays a major role. Without any stress, the $\mathrm{pH}$ in the cytoplasm is $(7.3-7.6)$; vacuoles (4.5 - 5.9); mitochondria (7.0); chloroplasts (7.2 7.8), and in apoplasm (5.5) [151]. Thus, it is found that the cytoplasm is neutral when compared with vacuoles and the apoplasm.

Detoxification of $\mathrm{Al}$ in the rhizosphere by organic acids occurs in the apoplasmtherefore, organic acid must be transported from the cytosol to the apoplasm. As mentioned above, in cytoplasm, organic acid anions are formed at neutral $\mathrm{pH}(7.3$ - 7.6); these organic acid anions are transported out of the root cells. Al exposure triggers the release of a specific carboxylate from a cytoplasm that contains a number of different carboxylate species. Therefore, activation of a particular carboxylate transporter is required that presumably resides in the root cell plasma membrane. In maize and wheat, this transport system has been identified as an anion channel $[43,148$, 149,152]. Anion channels are the membrane bound transport proteins that allow the passive flow of anions down their electrochemical gradient [15]. Using the patch clamp technique, protoplast isolated from root tips of Al-resistant wheat, anion channels have been identified in the plasma membrane that are specifically activated by extracellular $\mathrm{Al}^{3+}$. These anionic channels are permeable to malate and chloride [148,149]. Anion channel is more active and open more frequently in root tip protoplast of the Al-tolerant wheat genotype compared with those from the sensitive one. In root tip cells 
from Al-resistant maize, a similar anion channel has been identified where $\mathrm{Al}$-activated root citrate release is correlated with resistance $[43,150]$.

Three possibilities have been proposed for, how $\mathrm{Al}$ can activate these anion channels [6].

1) Interaction of $\mathrm{Al}$ directly with the channel protein triggers its opening.

2) After entering into the cytoplasm Al directly or indirectly activates the channel through signal cascade.

3) Interaction of $\mathrm{Al}$ with a specific receptor on the membrane surface with membrane itself for the initiation of a secondary messenger cascade which then activates the channel.

It is still unclear, what is the reason behind release of large amount of organic acid from the Al-tolerant genotype than Al-sensitive genotype. Researchers are assuming that there might be differences in the number of channel proteins in the membrane of each genotype, in their permeability to organic anions or in their activation by $\mathrm{Al}[15]$.

\section{Al-Resistant Mechanism Involves Detoxification of Internal Al through Organic Acids}

In some plant species that are highly tolerant, accumulation of high concentration of $\mathrm{Al}$ in the above ground herbage is observed without showing symptoms of $\mathrm{Al}$ toxicity i.e. they have the ability of accumulating $\mathrm{Al}$ in its shoots and roots. For example-Hydrangea macrophylla is an ornamental plant whose sepals turn from red to blue with increasing $\mathrm{Al}$ concentration [130]. This blue color is due to the formation of a complex of $\mathrm{Al}$ with two compounds, delphinindin-3-glucoside and 3-caffeolylquinic acid that are present in Hydrangea macrophylla sepals [153].

$\mathrm{Al}$ can bind to oxygen ligand with a greater affinity than any other element. $\mathrm{Al}^{3+}$ form of $\mathrm{Al}$ has $10^{7}$ times stronger binding affinity with ATP than does $\mathrm{Mg}^{2+}$ for binding sites on ATP [154]. Therefore, for the resistance from Al, plants must possess effective mechanism for the detoxification of internal $\mathrm{Al}^{3+}$. Three $\mathrm{Al}$ accumulator species have been identified recently that are involved in the detoxification of internal $\mathrm{Al}^{3+}$ by forming $\mathrm{Al}$ organic acid complexes.

$\mathrm{Al}$, in leaves, exists primarily as a 1:1 Al-citrate complex. A second Al-accumulator in buckwheat (Fagopyrum esculentum), in which complexes of Al-oxalate as $1: 3$, have been identified $[127,155]$.

$\mathrm{Al}$ undergoes a ligand exchange from oxalate to citrate when it is transported into the xylem and is exchanged back with oxalate when in the leaves. Detoxification of $\mathrm{Al}$ is subsequently followed by the storage of Al-organic acid complex in the vacuole [14]. Tonoplast localized mechanism mediating the transport of $\mathrm{Al}$ into the vacuole, as well as the nature of substrate (i.e. free $\mathrm{Al}$ versus $\mathrm{Al}$ carboxylate complexes) remain unknown [12].

\section{Other Al-Tolerance Mechanisms}

Where release of organic acids is one of the most important mechanisms used by plants against Al-toxicity, some plant species do not rely on these mechanisms. For example, Brachiaria decumbans does not secrete organic acids in response to $\mathrm{Al}$ [156]. As Al toxicity is largely dependent on $\mathrm{pH}$, thus, increase the $\mathrm{pH}$ around root apices by any mechanism, and may provide protection against toxicity. For example, Al-tolerant Arabidopsis mutant (alr1) exhibit an Al-induced increase in $\mathrm{pH}$, surrounding the root apex which results in decrease in $\mathrm{Al}^{3+}$ activity [138]. Efflux of phosphate is also one of the $\mathrm{Al}$ tolerance mechanisms. Phosphate combines with $\mathrm{Al}$ and form complexes and released along with malate, from the root apices of Atlas [136].

A number of studies had shown that Al toxicity may be due to oxidative stress and this induces the synthesis of proteins typical of oxidative stress responses. For example, Al induces the expression of genes that encode glutathione S-transferase, peroxidases and blue-copper proteins. It was observed that in Arabidopsis there was an increase in $\mathrm{Al}$ tolerance as well as increased tolerance to oxidative stress due to over-expression of some these induced proteins [157]. Study in yeast has also shown that $\mathrm{Al}$ tolerance is based on over-expression of genes rather than organic acid efflux [158].

\section{Discussion}

Al toxicity is the primary growth-limiting factor for plants in acid soils [159] and is most severe in soils with low base saturation, poor in $\mathrm{Ca}$ and $\mathrm{Mg}$ [5]. The primary limitations on acid soils are toxic levels of aluminum (Al) and manganese $(\mathrm{Mn})$, as well as suboptimal levels of phosphorous (P). This extensive root damage results in a reduced and damaged root system and limited water and mineral nutrient uptake [9]. Although $\mathrm{Al}$ resistance has been a successful and active area of research; however, the underlying molecular, genetic and physiological principles are still not well understood. The cellular components and processes which have been proposed to be affected by Al are wide ranging and some of the most important include; cell nuclei, mitosis and cell division [147], composition, physical properties and structure of the plasma membrane [116,117], uptake of $\mathrm{Ca}$ and other ions $[118,160]$, phosphoinositide-mediated signal transduction and cytoplasmic calcium homeostasis [20,52], oxidative stress [105], cytoskeletal dynamics [56] and the cell wall-plasma membrane-cytoskeleton continuum [61].

Malate exudation mechanism by wheat has been investigated most thoroughly [9] while citrate seems to be 
the most common organic acid anion exudated by Altolerant maize and snapbean [11]. In all three species secretion was greater (up to 10-fold) in Al-resistant cultivars than in Al-sensitive ones. Oxalate exudation in response to $\mathrm{Al}$ has also been observed in maize, but no differences between sensitive and tolerant varieties were detected [161].

Thus, it is observed that after $\mathrm{Al}^{3+}$ exposure, exudation of organic acids may occur either immediately (pattern I) or after a time delay (pattern II) $[15,150]$. But for longterm efflux of organic acid anions, continuous synthesis of organic acids inside the root cells is required [162] and for organic acid synthesis and metabolism, cytoplasmic $\mathrm{Mg}^{2+}$ activity plays important role in activation of many enzymes, such as, citrate synthase [163], malate dehydrogenase [164], malate synthase [165], iso-citrate dehydrogenase [166,167], malic enzyme [168], PEPC (phosphor enol pyruvate carboxylase) [169-171], and pyruvate kinase [172]. Even alleviation in $\mathrm{Al}^{3+}$ toxicity was found by addition of miliM concentrations of $\mathrm{Mg}$ in the external medium, by enhancingexudation of citrate in soybean [173] and rice bean [174]. It was also observed that pretreatment with $\mathrm{Mg}^{2+}$ enhanced the secretion of citrate within an hour compared with seedlings without $\mathrm{Mg}^{2+}$ pre-treatment $[175,176]$. The $\mathrm{Mg}^{2+}$ activity inside the cytoplasm are directly involved in the regulation of $\mathrm{H}^{+}$ATPase activity $[177,178]$. Thus, pretreatment with $\mathrm{Mg}^{2+}$ undersealed the citrate synthesis mechanism for release of organic acid. Somewhere, proton pumps $\left(\mathrm{H}^{+}\right.$-ATPase and $\mathrm{H}^{+}$-PPase), located in the plasma membrane and the tonoplast, respectively, also play important role by driving $\mathrm{H}^{+}$from the cytoplasm to either the apoplasm or the vacuole [179]. Hence, disturbance in $\mathrm{H}^{+}$-ATPase activity by $\mathrm{Al}^{3+}$ toxicity [180-182] would affect cytoplasmic $\mathrm{pH}$ regulation $[48,50]$.

\section{Conclusion}

Al toxicity is an important growth limiting factor for plants in acid soils which is comprised in a large area of fertile land, particularly in pH-5 or below. The morphological and physiological symptoms of $\mathrm{Al}$ toxicity in plants are often clearly recognizable. Tolerance to $\mathrm{Al}$ toxicity is clearly visible through differences in structure and function of plant parts. Metallic toxicity in tolerant and sensitive plant genotype was studied to determine specific gene(s) responsible for tolerance level and kind of amino acids which act as metallic chelator and detoxifier, level and forms of enzyme and changes in root permeability to ions and molecules and its mechanisms.

\section{Future Challenges}

Although considerable progress has been made in understanding Al-tolerance mechanisms based on organic acid efflux, much is still to be learned of the molecular mechanisms underlying the activation of anion-channels by Al. For instance, we need to better understanding of the processes involved in how a cell initially senses Al that then leads to channel gating and organic acid efflux. In addition, the genes encoding these anion channels need to be cloned. As indicated above, there are clearly Al tolerance mechanisms operating in plants that do not rely on organic acids but to date little is known about these mechanisms. Some progress has been made in genetically modifying plants to enhance their Al tolerance and future work is needed to ensure that sufficient levels of Al tolerance are obtained to be useful for agriculture.

\section{REFERENCES}

[1] H. R. Von Uexküll and E. Mutert, "Global Extent, Development and Economic Impact of Acid Soils," Plant Soil, Vol. 171, No. 1, 1995, pp. 1-15. http://dx.doi.org/10.1007/BF00009558

[2] A. J. Bot, F. O. Nachtergaele and A. Young, "Land Resource Potential and Constraints at Regional and Country Levels," Food and Agricultural Organization of the United Nations, Rome, 2000, pp. 114.

[3] S. A. Bhalerao and D. V. Prabhu, "Aluminium Toxicity in Plants-A Review," Journal of Applicable Chemistry, Vol. 2, No. 3, 2013, pp. 447-474.

[4] H. Eswaran, P. Reich and F. Beinroth, "Global Distribution of Soils with Acidity," In: A. C. Moniz, et al., Eds., Plant-Soil Interactions at Low pH, Brazilian Soil Science Society, 1997, pp. 159-164.

[5] V. A. Vitorello, F. R. C. Capaldi and V. A. Stefanuto, "Recent Advances in Aluminum Toxicity and Resistance in Higher Plants," Brazilian Journal of Plant Physiology, Vol. 17, No. 1, 2005, 129-143. http://dx.doi.org/10.1590/S1677-04202005000100011

[6] E. Delhaize and P. R. Ryan, "Aluminum Toxicity and Tolerance in Plants," Plant Physiology, Vol. 107, No. 2, 1995, pp. 315-321.

[7] H. Matsumoto, "Cell Biology of Aluminum Toxicity and Tolerance in Higher Plants," International Review of Cytology, Vol. 200, 2000, pp. 1-47.

http://dx.doi.org/10.1016/S0074-7696(00)00001-2

[8] M. Ciamporova, "Morphological and Structural Responses of Roots to Aluminium at Organ, Tissue and Cellular Levels," Journal of Plant Biology, Vol. 45, No. 2, 2002, pp. 161-171.

http://dx.doi.org/10.1023/A:1015159601881

[9] L. V. Kochian, "Cellular Mechanisms of Aluminum Toxicity and Resistance in Plants," Annual Review of Plant Physiology and Plant Molecular Biology, Vol. 46, No. 1, 1995, pp. 237-260.

http://dx.doi.org/10.1146/annurev.pp.46.060195.001321

[10] H. Matsumoto, Y. Yamamoto and S. R. Devi, "Aluminum Toxicity in Acid Soils. Plant Responses to Aluminum," In: M. N. V. Prassad, Ed., Metals in the Environment, Okayama University, Kurashiki, 2001, pp. 289-320. 
[11] J. Barceló and C. Poschenrieder, "Fast Root Growth Responses, Root Exudates, and Internal Detoxification as Clues to the Mechanisms of Aluminium Toxicity and Resistance: A Review," Environmental and Experimental Botany, Vol. 48, No. 1, 2002, pp. 75-92. http://dx.doi.org/10.1016/S0098-8472(02)00013-8

[12] L. V. Kochian, O. A. Hoeckenga and M. A. Pineros, "How Do Crop Plants Tolerate Acid Soils? Mechanisms of Aluminium Tolerance and Phosphorus Efficiency," Annual Review of Plant Biology, Vol. 55, 2004, pp. 459-493. http://dx.doi.org/10.1146/annurev.arplant.55.031903.1416 $\underline{55}$

[13] L. V. Kochian, M. A. Pineros and O. A. Hoekenga, "The Physiology, Genetics and Molecular Biology of Plant Aluminum Resistance and Toxicity," Plant and Soil, Vol. 274, No. 1-2, 2005, pp. 175-195. http://dx.doi.org/10.1007/s11104-004-1158-7

[14] J. F. Ma, "Role of Organic Acids in Detoxification of Aluminum in Higher Plants," Plant and Cell Physiology, Vol. 41, No. 4, 2000, pp. 383-390. http://dx.doi.org/10.1093/pcp/41.4.383

[15] J. F. Ma, P. R. Ryan and E. Delhaize, "Aluminium Tolerance in Plants and the Complexing Role of Organic Acids," Trends in Plant Science, Vol. 6, No. 6, 2001, pp. 273-278. http://dx.doi.org/10.1016/S1360-1385(01)01961-6

[16] P. R. Ryan, E. Delhaize and D. L. Jones, "Function and Mechanism of Organic Anion Exudation from Plant Roots," Annual Review of Plant Physiology and Plant Molecular Biology, Vol. 52, No. 1, 2001, pp. 527-560. http://dx.doi.org/10.1146/annurev.arplant.52.1.527

[17] S. Miyasaka, J. Bute, R. Howell and C. D. Foy, "Mechanisms of Aluminum Tolerance in Snapbeans (Root Exudation of Citric Acid)," Plant Physiology, Vol. 96, 1991, pp. 737-743. http://dx.doi.org/10.1104/pp.96.3.737

[18] E. Delhaize, S. Craig, C. D. Beaton, R. J. Bennet, V. C. Jagadish and P. J. Randall, "Aluminum Tolerance in Wheat (Triticumaestivum L.): I. Uptake and Distribution of Aluminum in Root Apices," Plant Physiology, Vol. 103, No. 3, 1993, pp. 685-693.

[19] E. Delhaize, S. Craig, C. D. Beaton, R. J. Bennet, V. C. Jagadish and P. J. Randall, "Aluminum Tolerance in Wheat (Triticumaestivum L.) II. Aluminum-Stimulated Excretion of Malic Acid from Root Apices," Plant Physiology, Vol. 103, No. 3, 1993, pp. 695-702.

[20] D. L. Jones and L. V. Kochian, "Aluminum Inhibition of the Inositol 1,4,5-Trisphosphate Signal Transduction Pathway in Wheat Roots: A Role in Aluminum Toxicity?" Plant Cell, Vol. 7, No. 11, 1995, pp. 1913-1922.

[21] A. Haug and V. Vitorello, "Aluminum Coordination to Calmodulin: Thermodynamic and Kinetic Aspects," Coordination Chemistry, Vol. 149, No. 6931, 1996, pp. 113124.

[22] T. Watanabe and M. Osaki, "Mechanisms of Adaptation to High Aluminum Condition in Native Plant Species Growing in Acid Soils: A Review," Communications in Soil Sciences and Plant Analysis, Vol. 33, No. 7-8, 2002, pp. 1247-1260. http://dx.doi.org/10.1081/CSS-120003885

[23] T. Mossor-Pietraszewska, M. Kwit and M. Legiewicz,
"The Influence of Aluminium Ions on Activity Changes of Some Dehydrogenases and Amino Transferases in Yellow Lupine," Biological Bulletin of Poznañ, Vol. 34, No. 1, 1997, pp. 47-48.

[24] S. Lindberg, K. Szynkier and M. Greger, "Aluminum Effects on Transmembrane Potential in Cells of Fibrous Roots of Sugar Beet," Plant Physiology, Vol. 83, No. 1, 1991, pp. 54-62. http://dx.doi.org/10.1111/j.1399-3054.1991.tb01281.x

[25] L. A. Papernik and L. V. Kochian, "Possible Involvement of Aluminum-Induced Electrical Signals in Aluminum Tolerance in Wheat," Plant Physiology, Vol. 115, No. 2, 1997, pp. 657-667.

[26] S. C. Miyasaka, L. V. Kochian, J. E. Shaff and C. D. Foy, "Mechanisms of Aluminum Tolerance in Wheat (An Investigation of Genotypic Differences in Rhizosphere $\mathrm{pH}$, $\mathrm{K}^{+}$, and $\mathrm{H}^{+}$Transport and Root-Cell Membrane Potentials)," Plant Physiology, Vol. 91, No. 3, 1989, pp. 11881196. http://dx.doi.org/10.1104/pp.91.3.1188

[27] Z. Rengel and R. J. Reid, "Uptake of Al across the Plasma Membrane of Plant Cells," Plant and Soil, Vol. 192, No. 1, 1997, pp. 31-35. http://dx.doi.org/10.1023/A:1004265913770

[28] Q. Liu, J. L. Yang, L. S. He, Y. Y. Li and S. J. Zheng, "Effect of Aluminum on Cell Wall, Plasma Membrane, Antioxidants and Root Elongation in Triticale," Biologia Plantarum, Vol. 52, 2008, pp. 87-92. http://dx.doi.org/10.1007/s10535-008-0014-7

[29] S. Marienfeld, H. Lehmann and R. Stelzer, "Ultrastructural Investigations and EDX-Analyses of Al-Treated Oat (Avena sativa) Roots," Plant and Soil, Vol. 171, No. 1, 1995, pp. 167-173. http://dx.doi.org/10.1007/BF00009582

[30] N. Schmohl and W. J. Horst, "Cell Wall Pectin Content Modulates Aluminium Sensitivity of Zea mays (L.) Cells Grown in Suspension Culture," Plant Cell and Environment, Vol. 23, No. 7, 2000, pp. 735-742. http://dx.doi.org/10.1046/j.1365-3040.2000.00591.x

[31] Y. C. Chang, Y. Yamamoto and H. Matsumoto, “Accumulation of Aluminium in the Cell Wall Pectin in Cultured Tobacco (Nicotianatabacum L.) Cells Treated with a Combination of Aluminium and Iron," Plant Cell and Environment, Vol. 22, No. 8, 1999, pp. 1009-1010. http://dx.doi.org/10.1046/j.1365-3040.1999.00467.x

[32] F. P. C. Blamey, "The Role of the Root Cell Wall in Aluminium Toxicity," In: N. Ae, J. Arihara, K. Okada and A. Srinivasan, Eds., Plant Nutrient Acquisition, New Perspectives, Springer Verlag, New York, 2001, pp. 201-226. http://dx.doi.org/10.1007/978-4-431-66902-9_9

[33] H. Matsumoto, S. Morimura and E. Takahashi, "Less Involvement of Pectin in the Precipitation of Aluminum in Pea Root," Plant and Cell Physiology, Vol. 18, 1977, pp. 325-335.

[34] M. Rincon and R. Gonzales, "Aluminum Partitioning Intact Roots of Aluminium-Tolerant and AluminumSensitive Wheat (Triticumaestivum L.) Cultivars," Plant Physiology, Vol. 99, No. 3, 1992, pp. 1021-1022. http://dx.doi.org/10.1104/pp.99.3.1021

[35] A. Tabuchi and H. Matsumoto, "Changes in Cell-Wall 
Properties of Wheat (Triticumaestivum) Roots during Aluminum-Induced Growth Inhibition," Physiology of Plant, Vol. 112, 2001, pp. 353-358. http://dx.doi.org/10.1034/j.1399-3054.2001.1120308.x

[36] A. J. Kuhn, W. H. Schroder and J. Bauch, "The Kinetics of Calcium and Magnesium Entry into Mycorrhizal Spruce Roots," Planta, Vol. 210, No. 3, 2000, pp. 488-496. http://dx.doi.org/10.1007/PL00008156

[37] R. J. Reid, Z. Rengel and F. A. Smith, "Membrane Fluxes and Comparative Toxicities of Aluminium, Scandium and Gallium," Journal of Experimental Botany, Vol. 47, No. 12, 1996, pp. 1881-1888. http://dx.doi.org/10.1093/jxb/47.12.1881

[38] G. J. Taylor, J. L. Stephens, D. B. Hunte, P. M. Bertsch, D. Elmore, Z. Rengel and R. Reid, "Direct Measurement of Aluminium Uptake and Distribution in Single Cells of Chara corallina," Plant Physiology, Vol. 123, No. 3, 2000, pp. 987-996. http://dx.doi.org/10.1104/pp.123.3.987

[39] M. A. Akeson, D. N. Munns and R. G. Burau, "Adsorption of $\mathrm{Al}^{3+}$ to Phosphotidylcholine Vesicles," Biochimica et Biophysica Acta, Vol. 986, No. 1, 1989, pp. 33-40.

[40] T. B. Kinraide, P. R. Ryan and L. V. Kochian, "Interactive Effects of $\mathrm{Al}^{3+}, \mathrm{H}^{+}$and Other Cations on Root Elongation Considered in Terms of Cell-Surface Electrical Potential," Plant Physiology, Vol. 99, No. 4, 1992, pp. 1461-1468. http://dx.doi.org/10.1104/pp.99.4.1461

[41] S. J. Ahn, M. Sivaguru, G. C. Chung, Z. Rengel and H Matsumoto, "Aluminium-Induced Growth Inhibition Is Associated with Impaired Efflux and Influx of $\mathrm{H}^{+}$across the Plasma Membrane in Root Apices of Squash (Cucurbita pepo)," Journal of Experimental Botany, Vol. 53, No. 376, 2002, pp. 1959-1966. http://dx.doi.org/10.1093/jxb/erf049

[42] C. Poschenrieder, M. Llugany and J. Barcelo, "ShortTerm Effects of $\mathrm{pH}$ and Aluminium on Mineral Nutrition in Maize Varieties Differing in Proton and Aluminium Tolerance," Journal of Plant Nutrition, Vol. 18, No. 7, 1995, pp. 1495-1507. http://dx.doi.org/10.1080/01904169509364998

[43] M. A. Piňeros and L. V. Kochian, "A Patch-Clamp Study on the Physiology of Aluminum Toxicity and Aluminum Tolerance in Maize. Identification and Characterization of $\mathrm{Al}^{3+}$-Induced Anion Channels," Plant Physiology, Vol. 125, No. 1, 2001, pp. 292-305. http://dx.doi.org/10.1104/pp.125.1.292

[44] E. D. Mariano and W. G. Keltjens, "Long-Term Effects of Aluminium Exposure on Nutrient Uptake by Maize Ge- notypes Differing in Aluminium Resistance," Journal of Plant Nutrition, Vol. 28, No. 2, 2005, pp. 323-333. http://dx.doi.org/10.1081/PLN-200047625

[45] M. Shivaguru, T. Fujiwara, J. Samaj, F. Baluska, Z. Yang, H. Osawa, T. Maeda, T. Mori, D. Volkmann and H. Matsumoto, "Aluminum-Induced $1 \rightarrow 3-\beta$-D-Glucan Inhibits Cell-to-Cell Trafficking of Molecules through Plasmodesmata. A New Mechanism of Aluminum Toxicity in Plants," Plant Physiology, Vol. 124, No. 3, 2000, pp. 9911006. http://dx.doi.org/10.1104/pp.124.3.991

[46] D. L. Godbold and G. Jentschke, "Aluminium Accumula- tion in Root Cell Walls Coincides with Inhibition of Root Growth But Not with Inhibition of Magnesium Uptake in Norway Spruce," Physiologia Plantarum, Vol. 102, No. 4, 1998, pp. 553-560.

http://dx.doi.org/10.1034/j.1399-3054.1998.1020410.x

[47] I. R. Silva, T. J. Smyth, D. F. Moxley, T. E. Carter, N. S. Allen and T. W. Rufty, "Aluminum Accumulation at Nuclei of Cells in the Root Tip. Fluorescence Detection Using Lumogallion and Confocal Laserscanning Microscopy," Plant Physiology, Vol. 123, No. 2, 2000, pp. 543552. http://dx.doi.org/10.1104/pp.123.2.543

[48] O. Babourina and Z. Rengel, "Uptake of Aluminium into Arabidopsis Root Cells Measured by Fluorescent Lifetime Imaging," Annals of Botany, Vol. 104, No. 1, 2009, pp. 189-195. http://dx.doi.org/10.1093/aob/mcp098

[49] J. X. Xia, N. Yamaji, T. Kasai and J. A. F. Ma, "Plasma Membrane-Localized Transporter for Aluminum in Rice," Proceedings of the National Academy of Sciences of the United States of America, Vol. 107, No. 43, 2010, pp. 18381-18385. http://dx.doi.org/10.1073/pnas.1004949107

[50] J. Bose, O. Babourina, S. Shabala and Z. Rengel, "Aluminium-Dependent Dynamics of Ion Transport in Arabidopsis: Specificity of Low $\mathrm{pH}$ and Aluminium Responses," Physiologia Plantarum, Vol. 139, 2010, pp. 401412.

[51] C. Plieth, B. Sattelmacher, U. P. Hansen and M. R. Knight, "Low-pH Mediated Elevations in Cytosolic Calcium Are Inhibited by Aluminium: A Potential Mechanism for Aluminium Toxicity," The Plant Journal, Vol. 18, No. 6, 1999, pp. 643-650. http://dx.doi.org/10.1046/j.1365-313x.1999.00492.x

[52] Z. Rengel and W. H. Zhang, "Role of Dynamics of Intracellular Calcium in Aluminium Toxicity Syndrome," New Phytologist, Vol. 159, No. 2, 2003, pp. 295-314. http://dx.doi.org/10.1046/j.1469-8137.2003.00821.x

[53] J. Bose, O. Babourina, S. Shabala and Z. Rengel, "Aluminium-Induced Ion Transport in Arabidopsis: The Relationship between Al Tolerance and Root Ion Flux," Journal of Experimental Botany, Vol. 61, No. 11, 2010, pp. 3163-3175. http://dx.doi.org/10.1093/jxb/erq143

[54] S. J. Ahn, M. Sivaguru, H. Osawa, G. G. Chung and H. Matsumoto, "Aluminum Inhibits the $\mathrm{H}^{+}$-ATPase Activity by Permanently Altering the Plasma Membrane Surface Potentials in Squash Roots," Plant Physiology, Vol. 126, No. 4, 2001, pp. 1381-1390. http://dx.doi.org/10.1104/pp.126.4.1381

[55] P. R. Ryan, J. E. Shaff and L. V. Kochian, "Aluminum Toxicity in Roots (Correlation among Ionic Currents, Ion Fluxes, and Root Elongation in Aluminum-Sensitive and Aluminum Tolerant Wheat Cultivars)," Plant Physiology, Vol. 99, No. 3, 1992, pp. 1193-1200. http://dx.doi.org/10.1104/pp.99.3.1193

[56] M. Shivaguru, F. Baluška, D. Volkmann, H. H. Felle and W. J. Horst, "Impacts of Aluminum on the Cytoskeleton of the Maize Root Apex. Short-Term Effects on the Distal Part of the Transition Zone," Plant Physiology, Vol. 119, No. 3, 1999, pp. 1073-1082. http://dx.doi.org/10.1104/pp.119.3.1073

[57] M. Sasaki, Y. Yamamoto and H. Matsumoto, "Aluminum 
Inhibits Growth and Stability of Cortical Microtubules in Wheat (Triticum aestivum) Roots," Soil Science Plant Nutrition, Vol. 43, No. 2, 1997, pp. 469-472. http://dx.doi.org/10.1080/00380768.1997.10414772

[58] M. Sasaki, Y. Yamamoto, J. F. Ma and H. Matsumoto, "Early Events Induced by Aluminum Stress in Elongating Cells of Wheat Roots," Soil Science Plant Nutrition, Vol. 78, 1997, pp. 1009-1014.

[59] E. J. D. Blancaflor and S. Gilroy, "Alterations in the Cytoskeleton Accompany Aluminum-Induced Growth Inhibition and Morphological Changes in Primary Roots of Maize," Plant Physiology, Vol. 118, No. 1, 1998, pp. 159172. http://dx.doi.org/10.1104/pp.118.1.159

[60] S. Grabski, E. Arnoys, B. Busch and M. Schindler, "Regulation of Actin Tension in Plant Cells by Kinases and Phosphatases," Plant Physiology, Vol. 116, No. 1, 1998, pp. 279-290. http://dx.doi.org/10.1104/pp.116.1.279

[61] W. J. Horst, N. Schmohl, M. Kollmeier, F. Baluska and M. Sivaguru, "Does Aluminum Affect Root Growth of Maize through Interaction with the Cell Wall-Plasma Membrane-Cytoskeleton Continuum?" Plant and Soil, Vol. 215, No. 2, 1999, pp. 163-174. http://dx.doi.org/10.1023/A:1004439725283

[62] G. Frantzios, B. Galatis and P. Apostolakos, "Aluminum Effects on Microtubule Organization in Dividing RootTip Cells of Triticum turgidum. I. Mitotic Cells," New Phytologist, Vol. 145, No. 2, 2000, pp. 211-224. http://dx.doi.org/10.1046/j.1469-8137.2000.00580.x

[63] G. Frantzios, B. Galatis and P. Apostolakos, "Aluminum Effects on Microtubule Organization in Dividing RootTip Cells of Triticum turgidum. II. Cytokinetic Cells," Journal of Plant Research, Vol. 114, No. 2, 2001, pp. 157-170. http://dx.doi.org/10.1007/PL00013979

[64] L. Alessa and L. Oliveira, "Aluminum Toxicity Studies in Vaucheria longicaulis var. Macounii (Xanthophyta, Tribophyceae). II. Effects on the F-Actin Array," Environmental and Experimental Botany, Vol. 45, No. 3, 2001, pp. 223-237. http://dx.doi.org/10.1016/S0098-8472(00)00088-5

[65] K. Schwarzerová, S. Zelenková, P. Nick and Z. Opatrný, "Aluminum-Induced Rapid Changes in the Microtubular Cytoskeleton of Tobacco Cell Lines," Plant and Cell Physiology, Vol. 43, No. 2, 2002, pp. 207-216. http://dx.doi.org/10.1093/pcp/pcf028

[66] M. Sivaguru, S. Pike, W. Gassmann and T. I. Baskin, "Aluminum Rapidly Depolymerizes Cortical Microtubules and Depolarizes the Plasma Membrane: Evidence That These Responses Are Mediated by a Glutamate Receptor," Plant and Cell Physiology, Vol. 44, 2003, pp. 667-675.

[67] S. Grabski and S. M. Chindler, "Aluminum Induces Rigor within the Actin Network of Soybean Cells," Plant Physiology, Vol. 108, No. 3, 1995, pp. 897-901.

[68] A. Tani, C. Inoue, Y. Tanaka, Y. Yamamoto, H. Kondo and S. Hiradate, "The Crucial Role of Mitochondrial Regulation in Adaptive Aluminium Resistance in Rhodotorula glutinis," Microbiology, Vol. 154, No. 11, 2008, pp. 3437-3446.

http://dx.doi.org/10.1099/mic.0.2007/016048-0
[69] N. G. Marinos, "Studies on Submicroscopic Aspects of Mineral Deficiencies. II. Nitrogen, Potassium, Sulfur, Phosphorus, and Magnesium Deficiencies in the Shoot Apex of Barley," American Journal of Botany, Vol. 50, 1963, No. 10, pp. 998-1005. http://dx.doi.org/10.2307/2439907

[70] I. Cakmak and E. A. Kirkby, "Role of Magnesium in Carbon Partitioning and Alleviating Photo-Oxidative Damage," Plant Physiology, Vol. 133, No. 4, 2008, pp. 692-704. http://dx.doi.org/10.1111/j.1399-3054.2007.01042.x

[71] Y. Yamamoto, Y. Kobayashi, S. R. Devi, S. Rikiishi and H. Matsumoto, "Aluminum Toxicity Is Associated with Mitochondrial Dysfunction and the Production of Reactive Oxygen Species in Plant Cells," Plant Physiology, Vol. 128, No. 1, 2002, pp. 63-72. http://dx.doi.org/10.1104/pp.010417

[72] E. Darko, H. Ambrus, E. Stefanovits-Banyai, J. Fodor, F. Bakos and B. Barnaba, "Aluminium Toxicity, Al Tolerance and Oxidative Stress in an Al-Sensitive Wheat Genotype and in Al-Tolerant Lines Developed by in Vitro Microspore Selection," Plant Science, Vol. 166, No. 3, 2004, pp. 583-591. http://dx.doi.org/10.1016/j.plantsci.2003.10.023

[73] L. Tamás, M. Šimonovičová, J. Huttová and I. Mistrík, "Aluminium Stimulated Hydrogen Peroxide Production of Germinating Barley Seeds," Environmental and Experimental Botany, Vol. 51, No. 3, 2004, pp. 281-288. http://dx.doi.org/10.1016/j.envexpbot.2003.11.007

[74] D. L. Jones, E. B. Blancaflor, L. V. Kochian and S. Gilroy, "Plant, Spatial Coordination of Aluminium Uptake, Production of Reactive Oxygen Species, Callose Production and Wall Rigidification in Maize Roots," Cell and Environment, Vol. 29, No. 7, 2006, pp. 1309-1318. http://dx.doi.org/10.1111/j.1365-3040.2006.01509.x

[75] O. Babourina, L. Ozturk, I. Cakmak and Z. Rengel, "Reactiveoxygen Species Production in Wheat Roots Is Not Linked with Changes in $\mathrm{H}^{+}$Fluxes during Acidic and Aluminium Stresses," Plant Signaling and Behavior, Vol. 1, No. 2, 2006. http://dx.doi.org/10.4161/psb.1.2.2591

[76] K. Tahara, T. Yamanoshita, M. Norisada, I. Hasegawa, H. Kashima, S. Sasaki and K. Kojima, "Aluminum Distribution and Reactive Oxygen Species Accumulation in Root Tips of Two Melaleuca Trees Differing in Aluminum Resistance," Plant and Soil, Vol. 307, No. 1-2, 2008, pp. 167-178. http://dx.doi.org/10.1007/s11104-008-9593-5

[77] E. Rezabal, J. M. Mercero, X. Lopez and J. M. Ugalde, "A Study of the Coordination Shell of Aluminum (III) and Magnesium (II) in Model Protein Environments: Thermodynamics of the Complex Formation and Metal Exchange Reactions," Journal of Inorganic Biochemistry, Vol. 100, No. 3, 2006, pp. 374-384.

http://dx.doi.org/10.1016/j.jinorgbio.2005.12.007

[78] R. J. Mailloux, R. Hamel and V. D. Appanna, "Aluminum Toxicity Elicits a Dysfunctional TCA Cycle and Succinate Accumulation in Hepatocytes," Journal of Biochemical and Molecular Toxicology, Vol. 20, No. 4, 2006, pp. 198-208. http://dx.doi.org/10.1002/jbt.20137

[79] C. D. Foy, J. A. Duke and T. E. Devine, "Tolerance of Soybean Germplasm to an Acid Tatum Subsoil," Journal of Plant Nutrition, Vol. 15, No. 5, 1992, pp. 527-547. 
http://dx.doi.org/10.1080/01904169209364339

[80] R. Minocha, S. C. Minocha, S. L. Long and W. C. Shortle, "Effects of Aluminium on DNA Synthesis, Cellular Polyamines, Polyamine Biosynthetic Enzymes and Inorganic Ions in Cell Suspension Cultures of a Woody Plant, Catharanthus roseus," Physiology of Plant, Vol. 85, No. 3, 1992, pp. 417-424. http://dx.doi.org/10.1111/j.1399-3054.1992.tb05806.x

[81] C. D. Foy, "Tolerance of Barley Cultivars to Anacid, Aluminium-Toxic Subsoil Related to Mineral Element Concentrations of Their Shoots," Journal of Plant Nutrition, Vol. 19, No. 10-11, 1996, pp. 1361-1380. http://dx.doi.org/10.1080/01904169609365205

[82] D. T. Krizek, C. D. Foy and R. M. Mirecki, "Influence of Aluminium Stress on Shoot and Root Growth of Contrasting Genotypes of Coleus," Journal of Plant Nutrition, Vol. 20, No. 9, 1997, pp. 1045-1060. http://dx.doi.org/10.1080/01904169709365317

[83] L. Galvez and R. B. Clark, "Nitrate and Ammonium Uptake and Solution $\mathrm{pH}$ Changes for Al-Tolerant and AlSensitive Sorghum (Sorghum bicolour) Genotypes Grown with and without Aluminium," Plant and Soil, Vol. 134, No. 1, 1991, pp. 179-188.

[84] R. P. Durieux, W. A. Jackson, E. J. Kamprath and R. H. Moll, "Inhibition of Nitrate by Aluminium in Maize," Plant and Soil, Vol. 151, No. 1, 1993, pp. 97-104. http://dx.doi.org/10.1007/BF00010790

[85] W. G. Keltjens and K. Tan, "Interactions between Aluminium, Magnesium and Calcium with Different Monocotyledonous and Dicotyledonous Plant Species," Plant and Soil, Vol. 155-156, No. 1, 1993, pp. 458-488. http://dx.doi.org/10.1007/BF00025089

[86] E. Olivaresa, E. Peñaa, E. Marcanob, J. Mostaceroc, G. Aguiara, M. Beníteza and E. Rengifoa, "Aluminum Accumulation and Its Relationship with Mineral Plant Nutrients in 12 Pteridophytes from Venezuela," Environmental and Experimental Botany, Vol. 65, No. 1, 2009, pp. 132-141. http://dx.doi.org/10.1016/j.envexpbot.2008.04.002

[87] E. D. Mariano, R. A. Jorge, W. G. Keltjens and M. Menossi, "Metabolism and Root Exudation of Organic Acid Anions under Aluminium Stress," Brazilian Journal of Plant Physiology, Vol. 17, No. 1, 2005, pp. 157-172. http://dx.doi.org/10.1590/S1677-04202005000100013

[88] A. Giannakoula, M. Moustakas, P. Mylona, I. Papadakis and T. Yupsanis, "Aluminum Tolerance in Maize is Correlated with Increased Levels of Mineral Nutrients, Carbohydrates and Proline, and Decreased Levels of Lipid Peroxidation and Al Accumulation," Journal of Plant Physiology, Vol. 165, No. 4, 2008, pp. 385-396. http://dx.doi.org/10.1016/j.jplph.2007.01.014

[89] S. Silva, O. Pinto-Carnide, P. Martins-Lopes, M. Matos, H. Guedes-Pinto and C. Santos, "Differential Aluminium Changes on Nutrient Accumulation and Root Differentiation in an Al Sensitive vs. Tolerant Wheat," Environmental and Experimental Botany, Vol. 68, No. 1, 2010, pp. 91-98. http://dx.doi.org/10.1016/j.envexpbot.2009.10.005

[90] T. W. Rufty Jr., C. T. Mackown, D. B. Lazof and T. E. Carter, "Effects of Aluminium on Nitrate Uptake and As- similation," Plant Cell and Environment, Vol. 18, 1995, pp. 1325-1331.

[91] H. Calba and B. Jaillard, "Effect of Aluminium on Ion Uptake and $\mathrm{H}^{+}$Release by Maize," New Phytologist, Vol. 137, No. 4, 1997, pp. 607-616. http://dx.doi.org/10.1046/j.1469-8137.1997.00858.x

[92] C. D. Foy and A. L. Fleming, "Aluminum Tolerance of Two Wheat Cultivars Related to Nitrate Reductase Activities," Journal of Plant Nutrition, Vol. 5, No. 11, 1982, pp. 1313-1333. http://dx.doi.org/10.1080/01904168209363064

[93] L. W. Gallagher, K. M. Soliman, C. O. Qualset, R. C. Huffaker and D. W. Rains, "Major Gene Control of Nitrate Reductase Activity in Common Wheat," Crop Science, Vol. 20, No. 6, 1980, pp. 717-721.

http://dx.doi.org/10.2135/cropsci1980.0011183X0020000 $\underline{60010 \mathrm{x}}$

[94] B. E. Nichol, L. A. Oliveira, A. D. M. Glass and M. Y. Siddiqi, "The Effects of Aluminum on the Influx of Calcium, Potassium, Ammonium, Nitrate, and Phosphate in an Aluminum-Sensitive Cultivar of Barley (Hordeumvulgare L.)," Plant Physiology, Vol. 101, No. 4, 1993, pp. 1263-1266.

[95] J. W. Huang, J. E. Shaff, D. L. Grunes and L. V. Kochian, "Aluminum Effects on Calcium Fluxes at the Root Apex of Aluminum-Tolerant and Aluminum-Sensitive Wheat Cultivars," Plant Physiology, Vol. 98, No. 1, 1992, pp. 230-237. http://dx.doi.org/10.1104/pp.98.1.230

[96] P. R. Furlani and R. B. Clark, "Screening Sorghum for Aluminium Tolerance in Nutrient Solutions," Agronomy Journal, Vol. 73, No. 4, 1981, pp. 587-594. http://dx.doi.org/10.2134/agronj1981.0002196200730004 $\underline{0005 x}$

[97] R. B. Clarka, P. A. Pierb, D. Knudsenc and J. W. Maranvillec, "Effect of Trace Element Deficiencies and Excesses on Mineral Nutrients in Sorghum," Journal of Plant Nutrition, Vol. 3, No. 1-4, 1981, pp. 357-374. http://dx.doi.org/10.1080/01904168109362844

[98] H. Marschner, "Mineral Nutrition of Higher Plants," 2nd Edition, Academic Press, London, 1995.

[99] A. Franka, R. Wibomb and R. Danielssonc, "Myocardial Cytochrome C Activity in Swedish Moose (Alcesalces L.) Affected by Molybdenosis," The Science of the Total Environment, Vol. 290, No. 1-3, 2002, pp. 121-129. http://dx.doi.org/10.1016/S0048-9697(01)01077-4

[100] R. L. Fox and E. J. Kamprath, "Phosphate Sorption Isotherms for Evaluating the Phosphate Requirements of Soils," Soil Science Society of America Journal, Vol. 34, No. 6, 1970, pp. 902-907. http://dx.doi.org/10.2136/sssaj1970.03615995003400060 $\underline{025 x}$

[101] D. A. Barber, M. Ebert and N. T. S. Evans, "The Movement of ${ }^{15} \mathrm{O}$ through Barley and Rice Plants," Journal of Experimental Botany, Vol. 13, No. 3, 1962, pp. 397-403. http://dx.doi.org/10.1093/jxb/13.3.397

[102] T. R. Bates and J. P. Lynch, "Stimulation of Root Hair Elongation in Arabidopsis thaliana by Low Phosphorus Availability," Plant Cell Environment, Vol. 19, No. 5, 1996, pp. 529-538. 
http://dx.doi.org/10.1111/j.1365-3040.1996.tb00386.x

[103] D. Foehse and A. Jungk, "Influence of Phosphate and Nitrate Supply on Root Hair Formation of Rape, Spinach and Tomato Plants," Plant and Soil, Vol. 74, No. 3, 1983, pp. 359-368. http://dx.doi.org/10.1007/BF02181353

[104] E. Smitha, R. Naidu and A. M. Alstonb, "Chemistry of Inorganic Arsenic in Soils: II. Effect of Phosphorus, Sodium, and Calcium on Arsenic Sorption," Journal of Environmental Quality, Vol. 31, No. 2, 2002, pp. 557-563. http://dx.doi.org/10.2134/jeq2002.0557

[105] Y. Yamamoto, Y. Kobayashi, S. R. Devi, S. Rikiishi and H. Matsumoto, "Oxidative Stress Triggered by Aluminum in Plant Roots," Plant Soil, Vol. 255, No. 1, 2003, pp. 239-243. http://dx.doi.org/10.1023/A:1026127803156

[106] P. R. S. Boscolo, M. Menossi and R. A. Jorge, "Aluminum-Induced Oxidative Stress in Maize," Phytochemistry, Vol. 62, No. 2, 2003, pp. 181-189.

http://dx.doi.org/10.1016/S0031-9422(02)00491-0

[107] M. C. Kuo and C. H. Kao, "Aluminum Effects on Lipid Peroxidation and Antioxidative Enzyme Activities in Rice Leaves," Biologia Plantarum, Vol. 46, No. 1, 2003, pp. 149-152. http://dx.doi.org/10.1023/A:1022356322373

[108] Y. Yamamoto, Y. Kobayashi and H. Matsumoto, "Lipid Peroxidation Is an Early Symptom Triggered by Aluminum, But Not the Primary Cause of Elongation Inhibition in Pea Roots," Plant Physiology, Vol. 125, No. 1, 2001, pp. 199-208. http://dx.doi.org/10.1104/pp.125.1.199

[109] M. A. R. Rodriguez Milla, E. Butler, A. R. Huete, C. F. Wilson, O. Anderson and J. P. Gustafson, "Expressed Sequenced Tag-Based Gene Expression Analysis under Aluminum Stress in Rye," Plant Physiology, Vol. 130, No. 4, 2002, pp. 1706-1716. http://dx.doi.org/10.1104/pp.009969

[110] K. Apel and H. Hirt, "Reactive Oxygen Species: Metabolism, Oxidative Stress, and Signal Transduction," Annual Review of Plant Biology, Vol. 55, 2004, pp. 373-399. http://dx.doi.org/10.1146/annurev.arplant.55.031903.1417 $\underline{01}$

[111] B. Meriga, H. I. Attitalla, M. Ramgopal, M. Ediga and P. B. Kavikishor, "Differential Tolerance to Aluminium Toxicity in Rice Cultivars: Involvement of Antioxidative Enzymes and Possible Role of Aluminium Resistant Locus," Academy Journal of Plant Science, Vol. 3, No. 2, 2010, pp. 53-63.

[112] P. Dundek, L. Holik, T. Rohlik, V. Vranova, K. Rejsek and P. Formanek, "Methods of Plant Root Exudates Analysis: A Review," Acta Universitatis Agriculturae et Silviculturae Mendelianae Brunensis, Vol. 59, 2011, pp. 241-246.

[113] J. Bose, O. Babourina and Z. Rengel, "Role of Magnesium in Alleviation of Aluminium Toxicity in Plants," Journal of Experimental Botany, Vol. 62, No. 7, 2011, pp. 2251-2264. http://dx.doi.org/10.1093/jxb/erq456

[114] V. M. M. Achary, N. L. Parinandi and B. B. Panda, "Mutation Research/Genetic Toxicology and Environmental Mutagenesis," Mutation Research, Vol. 751, No. 2, 2013, pp. 130-138.

http://dx.doi.org/10.1016/j.mrgentox.2012.12.008
[115] M. P. C. Rosa, V. Vives, I. Z. Sara, F. L. C. María, V. Muñoz and G. C. Aurelio, "Biotechnological Approaches to Study Plant Responses to Stress," BioMed Research International, Vol. 2013, 2013, Article ID: 654120,

[116] G. Zhang, J. J. Slaski, D. J. Archambault and G. J. Taylor, "Alteration of Plasma Membrane Lipids in AluminumResistant and Aluminum-Sensitive Wheat Genotypes in Response to Aluminum Stress," Physiologia Plantarum, Vol. 99, No. 2, 1997, pp. 302-308.

http://dx.doi.org/10.1111/j.1399-3054.1997.tb05416.x

[117] S. Ishikawa and T. Wagatsuma, "Plasma Membrane Permeability of Root-Tip Cells Following Temporary Exposure to Al Ions Is a Rapid Measure of Al Tolerance among Plant Species," Plant Cell Physiology, Vol. 39, No. 5, 1998, pp. 516-525. http://dx.doi.org/10.1093/oxfordjournals.pcp.a029399

[118] K. Liu and S. Luan, "Internal Aluminum Block of Plant Inward K ${ }^{+}$Channels," Plant Cell, Vol. 13, No. 6, 2001, pp. 1453-1465.

[119] D. L. Jones and L. V. Kochian, "Aluminum Interaction with Plasma Membrane Lipids and Enzyme Metal Binding Sites and Its Potential Role in Al Cytotoxicity," FEBS Letters, Vol. 400, No. 1, 1997, pp. 51-57. http://dx.doi.org/10.1016/S0014-5793(96)01319-1

[120] P. C. Kerridge and W. E. Konstad, "Evidence of Genetic Resistance to Aluminum Toxicity in Wheat (Triticumaestivum Vill., Host)," Agronomy Journal, Vol. 60, No. 6, 1968, pp. 710-711.

http://dx.doi.org/10.2134/agronj1968.0002196200600006 $\underline{0041 \mathrm{x}}$

[121] W. A. Berzonsky, "The Genomic Inheritance of Aluminum Tolerance in 'Atlas 66' Wheat," Genome, Vol. 35, No. 4, 1992, pp. 689-693.

http://dx.doi.org/10.1139/g92-104

[122] J. P. Johnson, B. F. Carver and V. C. Baligar, "Expression of Aluminum Tolerance Transferred from Atlas 66 to Hard Winter Wheat," Crop Science, Vol. 37, No. 1, 1997, pp. 103-108.

http://dx.doi.org/10.2135/cropsci1997.0011183X0037000 $10016 \mathrm{x}$

[123] E. Polle, C. F. Konzak and J. A. Kittrick, "Visual Detection of Aluminum Tolerance Levels in Wheat by Hematoxylin Staining," Crop Science, Vol. 18, No. 5, 1978, pp. 823-827.

http://dx.doi.org/10.2135/cropsci1978.0011183X0018000 $\underline{50035 x}$

[124] P. R. Ryan, E. Delhaize and P. J. Randall, "Characterization of Al-Stimulated Efflux of Malate from the Apices of Al Tolerant Wheat Roots," Planta, Vol. 196, No. 1, 1995, pp. 103-110. http://dx.doi.org/10.1007/BF00193223

[125] P. R. Ryan, E. Delhaize and P. J. Randall, "Malate Efflux from Root Apices and Tolerance to Aluminum Are Highly Correlated in Wheat," Australian Journal of Plant Physiology, Vol. 22, No. 4, 1995, pp. 531-536. http://dx.doi.org/10.1071/PP9950531

[126] J. F. Ma, S. J. Zheng, S. Hiradate and H. Matsumoto, "Detoxifying Aluminum with Buckwheat," Nature, Vol. 390, No. 6660, 1997, pp. 569-570. http://dx.doi.org/10.1038/37518 
[127] J. F. Ma, S. J. Zheng and H. Matsumoto, "Specific Secretion of Citric Acid Induced by Al Stress in Cassia tora L.," Plant Cell Physiology, Vol. 38, No. 9, 1997, pp. 1019-1025. http://dx.doi.org/10.1093/oxfordjournals.pcp.a029266

[128] E. Delhaize, P. R. Ryan and P. J. Randall, "Aluminum Tolerance in Wheat (Triticum aestivum L.) (II. Aluminum-Stimulated Excretion of Malic Acid from Root Apices)," Plant Physiology, Vol. 103, No. 3, 1993, pp. 695702.

[129] D. M. Pellet, D. L. Grunes and L. V. Kochian, "Organic acid Exudation as an Aluminum Tolerance Mechanism in Maize (Zea mays L.)," Planta, Vol. 196, No. 4, 1995, pp. 788-795. http://dx.doi.org/10.1007/BF01106775

[130] J. F. Ma, S. Hiradate, K. Nomoto, T. Iwashita and H. Matsumoto, "Internal Detoxification Mechanism of $\mathrm{Al}$ in Hydrangea: Identification of Al Form in Leaves," Plant Physiology, Vol. 113, No. 1, 1997, pp. 1033-1039.

[131] Z. Ma and S. C. Miyasaka, "Oxalate Exudation by Taro in Response to Al," Plant Physiology, Vol. 118, No. 1, 1998, pp. 861-865. http://dx.doi.org/10.1104/pp.118.3.861

[132] S. J. Zheng, J. F. Ma and H. Matsumoto, "High Aluminum Resistance in Buckwheat: I. Al-Induced Special Secretion of Oxalic Acid from Root Tips," Plant Physiology, Vol. 117, No. 3, 1998, pp. 745-751.

[133] J. F. Ma and S. Hiradate, "Form of Aluminium for Uptake and Translocation in Buckwheat (Fagopyrum esculentum Moench)," Planta, Vol. 211, No. 3, 2000, pp. 355360. http://dx.doi.org/10.1007/s004250000292

[134] X. Li, J. Ma and H. Matsumoto, "Pattern of Aluminum Induced Secretion of Organic Acids Differs between Rye and Wheat," Plant Physiology, Vol. 123, No. 4, 2000, pp. 1537-1544. http://dx.doi.org/10.1104/pp.123.4.1537

[135] Z. M. Yang, M. Sivaguru, W. J. Horts and H. Matsumoto, "Aluminum Tolerance Is Achieved by Exudation of Citric Acid from Roots of Soybean (Glycine max)," Plant Physiology, Vol. 110, No. 1, 2000, pp. 72-74.

[136] D. M. Pellet, L. A. Papernik and L. V. Kochian, "Multiple Aluminum-Resistance Mechanisms in Wheat (Roles of Root Apical Phosphate and Malate Exudation)," Plant Physiology, Vol. 112, No. 2, 1996, pp. 591-597.

[137] E. Delhaize, P. R. Ryan, P. J. Hocking and A. E. Richardson, "Effects of Altered Citrate Synthase and Isocitrate Dehydrogenase Expression on Internal Citrate Concentrations and Citrate Efflux from Tobacco (Nicotiana tabacum L.) Roots," Plant and Soil, Vol. 248, No. 1-2, 2003, pp. 137-144. http://dx.doi.org/10.1023/A:1022352914101

[138] J. Dengenhardt, P. B. Larsen, S. H. Howell and L. V. Kochian, "Aluminum Resistance in the Arabidopsis Mutantalr-104 Is Caused by an Aluminum-Induced Increase in Rhizosphere pH," Plant Physiology, Vol. 117, No. 1, 1998, pp. 19-27. http://dx.doi.org/10.1104/pp.117.1.19

[139] M. E. LeNoble, D. G. Blevins, R. E. Sharp and B. G. Cumbie, "Prevention of Aluminium Toxicity with Supplemental Boron. I. Maintenance of Root Elongation and Cellular Structure," Plant, Cell \& Environment, Vol. 19, No. 10, 1996, pp. 1132-1142. http://dx.doi.org/10.1111/j.1365-3040.1996.tb00428.x

[140] G. Feng, F. S. Zhang, X. Li, C. Tian, C. Tang and Z. Rengel, "Improved Tolerance of Maize Plants to Salt Stress by Arbuscular mycorrhiza Is Related to Higher Accumulation of Soluble Sugars in Roots," Mycorrhiza, Vol. 12, No. 4, 2002, pp. 185-190.

http://dx.doi.org/10.1007/s00572-002-0170-0

[141] N. V. Hue, G. R. Craddock and F. Adams, "Effect of Organic Acids on Aluminum Toxicity in Subsoils," Soil Science of American Journal, Vol. 50, No. 1, 1986, pp. 2834.

http://dx.doi.org/10.2136/sssaj1986.03615995005000010 $\underline{006 \mathrm{x}}$

[142] M. Akeson and D. N. Munns, "Uptake of Aluminum into Root Cytoplasm; Predicted Rates for Important Solution Complexes," Journal of Plant Nutrition, Vol. 13, No. 5, 1990, pp. 467-484.

http://dx.doi.org/10.1080/01904169009364093

[143] B. Shi and A. Haug, "Aluminum Uptake by Neuro-Blastomacells," Journal of Neurochemistry, Vol. 55, No. 2, 1990, pp. 551-558. http://dx.doi.org/10.1111/j.1471-4159.1990.tb04169.x

[144] J. M. de la Fuente, V. Ramírez-Rodríguez, J. L. CabreraPonce and L. Herrera-Estrella, "Aluminum Tolerance in Transgenic Plants by Alteration of Citrate Synthesis," Science, Vol. 276, No. 5318, 2007, pp. 1566-1568. http://dx.doi.org/10.1126/science.276.5318.1566

[145] H. Koyama, A. Kawamura, T. Kihara, T. Hara, E. Takita and D. Shibata, "Overexpression of Mitochondrial Citrate Synthase in Arabidopsis thaliana Improved Growth on a Phosphorus Limited Soil," Plant and Cell Physiology, Vol. 41, No. 9, 2000, pp. 1030-1037. http://dx.doi.org/10.1093/pcp/pcd029

[146] M. Tesfaye, S. Temple, D. Allan, C. Vanc and D. Samac, "Overexpression of Malate Dehydrogenase in Transgenic Alfalfa Enhances Organic Acid Synthesis and Confers Tolerance to Aluminu," Plant Physiology, Vol. 127, No. 4, 2001, pp. 1836-1844. http://dx.doi.org/10.1104/pp.010376

[147] O. A. Hoekenga, T. J. Vision, J. E. Shaff, A. J. Monforte, G. P. Lee, S. H. Howell and L. V. Kochian, "Identification and Characterization of Aluminum Tolerance Loci in Arabidopsis (Landsberg erecta $\times$ Columbia) by Quantitative Trait Locus Mapping. A Physiologically Simple But Genetically Complex Trait," Plant Physiology, Vol. 132, No. 2, 2003, pp. 936-948. http://dx.doi.org/10.1104/pp.103.023085

[148] P. R. Ryan, M. Skerrett, G. Findlay, E. Delhaize and S. Tyerman, "Aluminum Activates an Anion Channel in the Apical Cells of Wheat Roots," Proceedings of the $\mathrm{Na}$ tional Academy of Sciences of the United States of America, Vol. 94, No. 12, 1997, pp. 6547-6552. http://dx.doi.org/10.1073/pnas.94.12.6547

[149] W. H. Zhang, P. Ryan and S. Tyerman, "Malate-Permeable Channels and Cation Channels Activated by Aluminum in the Apical Cells of Wheat Roots," Plant Physiology, Vol. 125, No. 3, 2001, pp. 1459-1472.

http://dx.doi.org/10.1104/pp.125.3.1459

[150] M. A. Piñeros1, J. V. Magalhaes1, V. M. Carvalho Alves 
and L. V. Kochian, "The Physiology and Biophysics of an Aluminum Tolerance Mechanism Based on Root Citrate Exudation in Maize," Plant Physiology, Vol. 129, No. 3, 2002, pp. 1194-1206.

[151] A. Kurkdjian and J. Guern, "Intracellular pH: Measurement and Importance in Cell Activity," Annual Review of Plant Physiology and Plant Molecular Biology, Vol. 40, 1989, pp. 271-303. http://dx.doi.org/10.1146/annurev.pp.40.060189.001415

[152] M. Kollmeier, P. Dietrich, C. S. Bauer, W. J. Horst and R. Hedrich, "Aluminum Activates a Citrate-Permeable Anion Channel in the Al-Sensitive Zone of the Maize Root Apex: A Comparison between an Al-Sensitive and an Al-Tolerant Cultivar," Plant Physiology, Vol. 126, No. 1, 2001, pp. 397-410. http://dx.doi.org/10.1104/pp.126.1.397

[153] K. Takeda, M. Kariuda and H. Itoi, "Blueing of Sepal Colour of Hydrangea macrophylla," Photochemistry, Vol. 24, No. 10, 1985, pp. 2251-2254. http://dx.doi.org/10.1016/S0031-9422(00)83019-8

[154] R. B. Martin, "The Chemistry of Aluminum as Related to Biology and Medicine," Clinical Chemistry, Vol. 32, No. 1986, pp. 1797-1806.

[155] J. F. Ma, S. Hiradate and H. Matsumoto, "High Aluminum Resistance in Buckwheat: II. Oxalic Acid Detoxifies Aluminum Internally," Plant Physiology, Vol. 117, No. 3, 1998, pp. 753-759. http://dx.doi.org/10.1104/pp.117.3.753

[156] P. Wenzl, G. M. Patino, A. L. Chaves, J. E. Mayer and I. M. Rao, "The High Level of Aluminum Resistance in Signal Grass Is Not Associated with Known Mechanisms of Aluminum Detoxification in Root Apices," Plant Physiology, Vol. 125, No. 3, 2001, pp. 1473-1484. http://dx.doi.org/10.1104/pp.125.3.1473

[157] B. Ezaki, R. C. Gardner and H. Matsumoto, "Expression of Aluminum-Induced Genes in Transgenic Arabidopsis Plants Can Ameliorate Aluminum Stress and/or Oxidative Stress," Plant Physiology, Vol. 122, No. 3, 2000, pp. 657-666. http://dx.doi.org/10.1104/pp.122.3.657

[158] C. W. MacDiarmid and R. C. Gardner, "Overexpression of the Saccharomyces cerevisiae Magnesium Transport System Confers Resistance to Aluminum Ion," The Journal of Biological Chemistry, Vol. 273, No. 3, 1998, pp. 1727-1732. http://dx.doi.org/10.1074/jbc.273.3.1727

[159] C. D. Foy, "Soil Chemical Factors Limiting Plant Root Growth," Advances in Soil Sciences: Limitations to Plant Root Growth, Vol. 19, 1992, pp. 97-149. http://dx.doi.org/10.1007/978-1-4612-2894-3_5

[160] P. R. Ryan and L. V. Kochian, "Interaction between Aluminum Toxicity and Calcium Uptake at the Root Apex in Near-Isogenic Lines of Wheat (Triticumaestivum L.) Differing in Aluminum Tolerance," Plant Physiology, Vol. 102, No. 3, 1993, pp. 975-982.

[161] P. S. Kidd, M. Llugany, C. Poschenrieder, B. Gunse and J. Barceló, "The Role of Root Exudates in Aluminium Resistance and Silicon-Induced Amelioration of Aluminium Toxicity in Tree Varieties of Maize (Zea mays L.)," Journal of Experimental Botany, Vol. 52, No. 359, 2001, pp. 1339-1352. http://dx.doi.org/10.1093/jexbot/52.359.1339
[162] U. Basu, D. Godbold and G. J. Taylor, "Aluminum Resistance in Triticum aestivum Associated with Enhanced Exudation of Malate," Journal of Plant Physiology, Vol. 144, No, 6, 1994, pp. 747-753.

[163] C. A. Boulton and C. Ratledge, "Regulatory Studies on Citrate Synthase in Candida 107, an Oleaginous Yeast," Microbiology, Vol. 121, No. 2, 1980, pp. 441-447. http://dx.doi.org/10.1099/00221287-121-2-441

[164] A. A. Iglesias and C. S. Andreo, "NADP-Dependent Malate Dehydrogenase (Decarboxylating) from Sugar Cane Leaves," European Journal of Biochemistry, Vol. 192, No. 3, 1990, pp. 729-733. http://dx.doi.org/10.1111/j.1432-1033.1990.tb19283.x

[165] B. R. Howard, J. A. Endrizzi and S. J. Remington, "Crystal Structure of Escherichia coli Malate Synthase G Complexed with Magnesium and Glyoxylate at $2.0 \AA$ Resolution: Mechanistic Implications," Biochemistry, Vol. 39, No. 11, 2000, pp. 3156-3168. http://dx.doi.org/10.1021/bi992519h

[166] Y. Satoh and Y. Nakamura, "Characteristics of the Reverse Reaction of NADP ${ }^{+}$-Isocitrate Dehydrogenase from Castor Bean Seeds," Physiologia Plantarum, Vol. 62, No. 4, 1984, pp. 561-565. http://dx.doi.org/10.1111/j.1399-3054.1984.tb02799.x

[167] S. A Doyle, P. T. Beernink and D. E. Koshland, "Structural Basis for a Change in Substrate Specificity: Crystal Structure of S113E Isocitrate Dehydrogenase in a Complex with Isopropylmalate, $\mathrm{Mg}^{2+}$, and NADP," Biochemistry, Vol. 40, No. 14, 2001, pp. 4234-4241. http://dx.doi.org/10.1021/bi002533q

[168] J. O. D. Coleman and J. M. Palmer, "The Oxidation of Malate by Isolated Plant Mitochondria," European Journal of Biochemistry, Vol. 26, No. 4, 1972, pp. 499-509. http://dx.doi.org/10.1111/j.1432-1033.1972.tb01792.x

[169] R. S. Bandurski, "Further Studies on the Enzymatic Synthesis of Oxalacetate from Phosphoenolpyruvate and Carbon Dioxide," Journal of Biological Chemistry, Vol. 217, 1955, pp. 137-150.

[170] M. H. O’Leary, "Phosphoenolpyruvate Carboxylase: An Enzymologist's View," Annual Review of Plant Physiology, Vol. 33, 1982, pp. 297-315.

http://dx.doi.org/10.1146/annurev.pp.33.060182.001501

[171] A. Tovar-Mendez, R. Rodriguez-Sotres, D. M. LopezValentin and R. A. Munoz-Clares, "Re-Examination of the Roles of PEP and $\mathrm{Mg}^{2+}$ in the Reaction Catalysed by the Phosphorylated and Nonphosphorylated Forms of Phosphoenolpyruvate Carboxylase from Leaves of Zea mays. Effects of the Activators Glucose 6-Phosphate and Glycine," Biochemical Journal, Vol. 332, 1998, pp. 633642.

[172] F. E. Podestá and W. C. Plaxton, "Plant Cytosolic Pyruvate Kinase: A Kinetic Study," Biochimica et Biophysica Acta, Vol. 1160, No. 2, 1992, pp. 213-220.

[173] I. R. Silva, T. J. Smyth, D. W. Israel, C. D. Raper and T. W. Rufty, "Magnesium Ameliorates Aluminum Rhizotoxicity in Soybean by Increasing Citric Acid Production and Exudation by Roots," Plant and Cell Physiology, Vol. 42, No. 5, 2001, pp. 546-554. http://dx.doi.org/10.1093/pcp/pce067 
[174] J. L. Yang, J. F. You, Y. Y. Li, P. Wu and S. J. Zheng, "Magnesium Enhances Aluminum-Induced Citrate Secretion in Rice Bean Roots (Vigna umbellata) by Restoring Plasma Membrane $\mathrm{H}^{+}$-ATPase Activity," Plant and Cell Physiology, Vol. 48, No. 1, 2007, pp. 66-73. http://dx.doi.org/10.1093/pcp/pcl038

[175] I. R. Silva, T. J. Smyth, D. W. Israel, C. D. Raper and T. W. Rufty, "Magnesium Is More Efficient than Calcium in Alleviating Aluminum Rhizotoxicity in Soybean and Its Ameliorative Effect Is Not Explained by the Gouy-Chapman-Stern Model," Plant and Cell Physiology, Vol. 42, No. 5, 2001, pp. 538-545. http://dx.doi.org/10.1093/pcp/pce066

[176] I. R. Silva, T. J. Smyth, D. W. Israel and T. W. Rufty, "Altered Aluminum Inhibition of Soybean Root Elongation in the Presence of Magnesium," Plant and Soil, Vol. 230, No. 2, 2001, pp. 223-230. http://dx.doi.org/10.1023/A:1010384516517

[177] R. J. Brooker and C. W. Slayman, "Effects of $\mathrm{Mg}^{2+}$ Ions on the Plasma Membrane [H+]-ATPase of Neurosporacrassa. II. Kinetic Studies," Journal of Biological Chemistry, Vol. 258, No. 14, 1983, pp. 8833-8838.

[178] M. S. Costa and L. de Meis, "Regulation of Plasma Mem- brane $\mathrm{H}^{+}$-ATPase from Corn Root by $\mathrm{Mg}^{2+}$ and $\mathrm{pH}$," Biochimicaet BiophysicaActa, Vol. 1279, No. 2, 1996, pp. 214-218

[179] F. Marty, "Plant Vacuoles," The Plant Cell, Vol. 11, No. 4, 1999, pp. 587-600.

[180] H. Matsumoto, "Inhibition of Proton Transport Activity of Microsomal Membrane Vesicles of Barley Roots by Aluminum," Soil Science and Plant Nutrition, Vol. 34, No. 4, 1988, pp. 499-506. http://dx.doi.org/10.1080/00380768.1988.10416466

[181] H. Matsumoto, Y. Yamamoto and M. Kasai, "Changes of Some Properties of the Plasma Membrane-Enriched Fraction of Barley Roots Related to Aluminum Stress: Membrane-Associated ATPase, Aluminum and Calcium," Soil Science and Plant Nutrition, Vol. 38, No. 3, 1992, pp. 411-419. http://dx.doi.org/10.1080/00380768.1992.10415073

[182] M. Sasaki, M. Kasai, Y. Yamamoto and H. Matsumoto, "Involvement of Plasma Membrane Potential in the Tolerance Mechanism of Plant Roots to Aluminum Toxicity," Plant and Soil, Vol. 171, No. 1, 1995, pp. 119-124. http://dx.doi.org/10.1007/BF000095 